Atmos. Chem. Phys., 18, 12663-12682, 2018

https://doi.org/10.5194/acp-18-12663-2018

(C) Author(s) 2018. This work is distributed under

the Creative Commons Attribution 4.0 License.

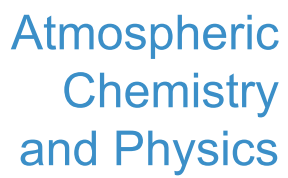

(c) (i)

\title{
Volatile organic compounds at a rural site in Beijing: influence of temporary emission control and wintertime heating
}

\author{
Weiqiang Yang ${ }^{1,3}$, Yanli Zhang ${ }^{1,2}$, Xinming Wang ${ }^{1,2,3}$, Sheng $\mathbf{L i}^{1,3}$, Ming $\mathbf{Z h u}^{1,3}$, Qingqing Yu ${ }^{1,3}$, Guanghui $\mathbf{L i}^{1,3}$, \\ Zhonghui Huang ${ }^{1,3}$, Huina Zhang ${ }^{1,3}$, Zhenfeng Wu ${ }^{1,3}$, Wei Song ${ }^{1}$, Jihua Tan ${ }^{3}$, and Min Shao ${ }^{4,5}$ \\ ${ }^{1}$ State Key Laboratory of Organic Geochemistry and Guangdong Key Laboratory of Environmental Protection and Resources \\ Utilization, Guangzhou Institute of Geochemistry, Chinese Academy of Sciences, Guangzhou 510640, China \\ ${ }^{2}$ Center for Excellence in Regional Atmospheric Environment, Institute of Urban Environment, \\ Chinese Academy of Sciences, Xiamen 361021, China \\ ${ }^{3}$ University of Chinese Academy of Sciences, Beijing 100049, China \\ ${ }^{4}$ State Joint Key Laboratory of Environmental Simulation and Pollution Control, College of Environmental Sciences \\ and Engineering, Peking University, Beijing 100871, China \\ ${ }^{5}$ Institute for Environmental and Climate Research, Jinan University, Guangzhou 511443, China
}

Correspondence: Yanli Zhang (zhang_yl86@gig.ac.cn) and Xinming Wang (wangxm@gig.ac.cn)

Received: 11 January 2018 - Discussion started: 22 February 2018

Revised: 16 July 2018 - Accepted: 8 August 2018 - Published: 31 August 2018

\begin{abstract}
While residential coal/biomass burning might be a major and underappreciated emission source for $\mathrm{PM}_{2.5}$, especially during winter, it is not well constrained whether burning solid fuels contributes substantially to ambient volatile organic compounds (VOCs), which are precursors to secondary organic aerosols (SOAs) that typically have a higher contribution to particulate matter during winter haze events. In this study, ambient air samples were collected in 2014 from 25 October to 31 December at a rural site on the campus of the University of Chinese Academy of Sciences (UCAS) in northeastern Beijing for the analysis of VOCs. Since temporary intervention measures were implemented on 3-12 November to improve the air quality for the AsianPacific Economic Cooperation (APEC) summit held on 511 November in Beijing, and wintertime central heating started on 15 November in Beijing after the APEC summit, this sample collection period provided a good opportunity to study the influence of temporary control measures and wintertime heating on ambient VOCs. As a result of the temporary intervention measures implemented during 3-12 November (period II), the total mixing ratios of non-methane hydrocarbons averaged $11.25 \mathrm{ppb}$, approximately $50 \%$ lower than the values of $23.41 \mathrm{ppb}$ in period I (25 October-2 November) and $21.71 \mathrm{ppb}$ in period III (13 November-31 December). The ozone and SOA for-
\end{abstract}

mation potentials decreased by $\sim 50 \%$ and $\sim 70 \%$, respectively, during period II relative to period I, with the larger decrease in SOA formation potentials attributed to more effective control over aromatic hydrocarbons mainly from solvent use. Back trajectory analysis revealed that the average mixing ratios of VOCs in southerly air masses were 2.3, 2.3 and 2.9 times those in northerly air masses during periods I, II and III, respectively; all VOC episodes occurred under the influence of southerly winds, suggesting much stronger emissions in the southern urbanized regions than in the northern rural areas. Based on a positive matrix factorization (PMF) receptor model, the altered contributions from traffic emissions and solvent use could explain $47.9 \%$ and $37.6 \%$ of the reduction in ambient VOCs, respectively, during period II relative to period I, indicating that the temporary control measures on vehicle emissions and solvent use were effective at lowering the ambient levels of VOCs. Coal/biomass burning, gasoline exhaust and industrial emissions were among the major sources, and they altogether contributed $60.3 \%$, $78.6 \%$ and $78.7 \%$ of the VOCs during periods I, II and III, respectively. Coal/biomass burning, mostly residential coal burning, became the dominant source, accounting for $45.1 \%$ of the VOCs during the wintertime heating period, with a specifically lower average contribution percentage in southerly air masses $(38.2 \%)$ than in northerly air masses 
$(48.8 \%)$. The results suggest that emission control in the industry and traffic sectors is more effective in lowering ambient reactive VOCs in non-heating seasons; however, during the winter heating season reducing emissions from residential burning of solid fuels would be of greater importance and would have health co-benefits from lowering both indoor and outdoor air pollution.

\section{Introduction}

Volatile organic compounds (VOCs) are precursors of tropospheric ozone and secondary organic aerosols (SOAs) (Forstner et al., 1997; Odum et al., 1997; Atkinson, 2000; O'Dowd et al., 2002; Sato et al., 2010). As ozone formation in urban areas is largely VOC limited (Shao et al., 2009; Tang et al., 2010) and SOAs are important components of fine particles or $\mathrm{PM}_{2.5}$ (particulate matter with an aerodynamic diameter less than $2.5 \mu \mathrm{m}$ ) (Cabada et al., 2004; Lonati et al., 2005; Huang et al., 2014), reducing emissions of VOCs would be very important for improving the air quality in megacities, such as China's capital city Beijing, where air pollution has become a widespread concern, with increasing surface ozone levels during summer and severe $\mathrm{PM}_{2.5}$ pollution during winter (Streets et al., 2007; Ji et al., 2012; Wang et al., 2014).

While exposure to indoor air pollution from burning solid fuels affects nearly half of the world's population and household air pollution has long been a major environmental cause of death (Martin et al., 2011; Lim et al., 2012; Subramanian, 2014), emissions from residential energy use such as heating and cooking, prevalent in India and China, also have the largest impact on global premature mortality from outdoor air pollution (Lelieveld et al., 2015). In fact, Juda-Rezler et al. (2011) showed that coal combustion in residential boilers during winter was a major source of $\mathrm{PM}_{10}$ in four cities of central eastern Europe. A recent study revealed that even in Beijing and its surrounding regions, residential use of solid fuels might be a major and underappreciated ambient pollution source for $\mathrm{PM}_{2.5}$ (particularly black carbon, $\mathrm{BC}$, and organic carbon, $\mathrm{OC}$ ) during the winter heating period (Liu et al., 2016). Since substantial quantities of VOCs are released from poor-technology burning of coal and biomass/biofuels (Yokelson et al., 2008; Shrivastava et al., 2015; Fang et al., 2017; Liu et al., 2017; Cheng et al., 2018), it is of wide concern how residential use of solid fuels, particularly for wintertime household heating, would influence ambient levels and composition of VOCs. In residential areas of Izmir, Turkey, for example, household burning of coal on uncontrolled burners for domestic heating during winter was found to be a larger source of VOCs than the local traffic (Sari and Bayram, 2014).

Due to a wide variety of emission sources of VOCs and large uncertainties of the emission inventories of VOCs, to formulate emission control measures to reduce ambient VOCs is a highly challengeable task. More field measurements are therefore needed to characterize VOCs in ambient air and in emission sources for better source attribution. In Beijing, for example, since higher levels of ozone mostly occur during hot seasons, many field measurements of VOCs were conducted in summer with a focus on their sources (Song et al., 2007; Lu et al., 2007; Yuan et al., 2009; B. Wang et al., 2010) and their mixing ratios (Liu et al., 2009; An et al., 2012; Y. J. Zhang et al., 2012; Liu et al., 2013), particularly during ozone episodes. Conversely, during extremely severe and persistent haze events in Beijing, organic matter $(\mathrm{OM})$ could contribute $30-70 \%$ of the total $\mathrm{PM}_{2.5}$ with higher fractions of SOA in OM (Guo et al., 2014; Huang et al., 2014; J. K. Zhang et al., 2014b). However, the effect of VOCs on wintertime $\mathrm{PM}_{2.5}$ pollution is much less understood, although the control of VOCs, as SOA precursors, is also of great importance in the control of $\mathrm{PM}_{2.5}$ air pollution. A previous study already demonstrated that levels of aromatic hydrocarbons and carbonyls increased significantly on haze days in urban Beijing from 2008 to 2010 (Y. J. Zhang et al., 2014), yet few reports are available about wintertime precursor VOCs, especially about the potential contribution of burning solid fuels for household heating.

Apart from health benefits from lowering indoor air pollution, controlling emissions in the residential sector would be of greater importance to further improve outdoor air quality worldwide in the future (Liu et al., 2016), although previously efforts have been overwhelmingly targeted at reducing emissions from industrial and traffic sectors in many regions. In northern China, for example, air quality has been greatly improved in recent years due to the implementation of longterm pollution control actions (Hao and Wang, 2005; Wang et al., 2009; Q. Zhang et al., 2012; Z. R. Liu et al., 2015; Kelly and Zhu, 2016). However, the air quality there is not satisfactory compared to that in cities in the United States and Europe, especially in winter, with frequent haze events and high $\mathrm{PM}_{2.5}$ levels. Consequently, during critical international events such as the 2008 Olympic Games (S. W. Wang et al., 2010; Huang et al., 2010) and the 2014 Asia-Pacific Economic Cooperation (APEC) summit, temporary intervention measures were adopted to guarantee better air quality. This type of temporary intervention provided a good opportunity to assess the relative importance of different sources and to study the effectiveness of various control measures on the reduction of ambient air pollutants including VOCs (Yao et al., 2013; Huang et al., 2017). For the 21st APEC summit held in Beijing on 5-11 November 2014, temporary control measures in Beijing and its surrounding regions resulted in a significant decrease in air pollutants, including $\mathrm{PM}_{2.5}$ and $\mathrm{NO}_{x}$ (Huang et al., 2015; J. G. Liu et al., 2015; Wang et al., 2015; Xu et al., 2015; J. K. Zhang et al., 2016). For the VOCs in ambient air, as observed by Li et al. (2015) at an urban site on the campus of Peking University, the total mixing ratios of VOCs were reduced by $44 \%$ during the APEC 
summit control period compared to those in the period before. As the 2008 Olympic Games and the 2014 APEC were held in the non-heating periods, it is not certain to what extent the temporary intervention measures mostly targeted at industrial and traffic emissions would take effect in the winter heating period.

While vehicle exhaust is an important source of VOCs in urban areas (McDonald et al., 2015; T. Liu et al., 2015; Ortega et al., 2016; Deng et al., 2017; Gentner et al., 2017), coal burning and biomass/biofuel burning may also contribute substantially to VOCs, particularly in winter when raw coal and biofuels are widely used for household heating in regions like northern China (Liu et al., 2016; Z. Zhang et al., 2016; Liu et al., 2017). In fact, a study by Wang et al. (2013) in 2011-2012 revealed that even at an urban site in Beijing, coal combustion could account for $28-39 \%$ of the VOCs observed in ambient air. As raw coal and/or biofuel burning widely occur in rural areas in winter (Liu et al., 2016), it is necessary to investigate extensively how enhanced emissions due to wintertime household heating would influence ambient VOCs in rural areas, as forming SOA or ozone is an issue on a regional scale.

In this study, ambient air samples were collected at a rural site in the north of Beijing from 25 October to 31 December 2014, covering the period with enhanced temporary emission control (3-12 November) for the APEC summit and the wintertime heating period starting from 15 November. The objectives of the present study are (1) to study changes in the mixing ratios and composition of VOCs at a rural site in Beijing in response to the emission control during the APEC summit and wintertime heating, (2) to identify the crucial sources of VOCs in Beijing and their changes during the PMpolluted winter, (3) to evaluate the impact of control measures implemented during the APEC summit on the reduction of VOCs in ambient air in rural areas, and (4) to assess the contribution of residential use of solid fuels for household heating to ambient VOCs during winter.

\section{Methodology}

\subsection{Sampling site and field sampling}

The ambient air samples were collected at a site $\left(40.41^{\circ} \mathrm{N}\right.$, $116.68^{\circ} \mathrm{E}$; Fig. 1) on the campus of the University of Chinese Academy of Science (UCAS) in the Huairou district of Beijing. UCAS is located approximately $60 \mathrm{~km}$ northeast of central Beijing and approximately $150 \mathrm{~km}$ northwest of the city of Tianjin. It is surrounded by several small villages and farmland. The samples were collected about $16 \mathrm{~m}$ above the ground on top of a four-story building, approximately $100 \mathrm{~m}$ west of a national road and only $1.5 \mathrm{~km}$ away from the main APEC conference hall.

Ambient air samples were collected from 25 October to 31 December 2014 using cleaned and evacuated 2L silica-

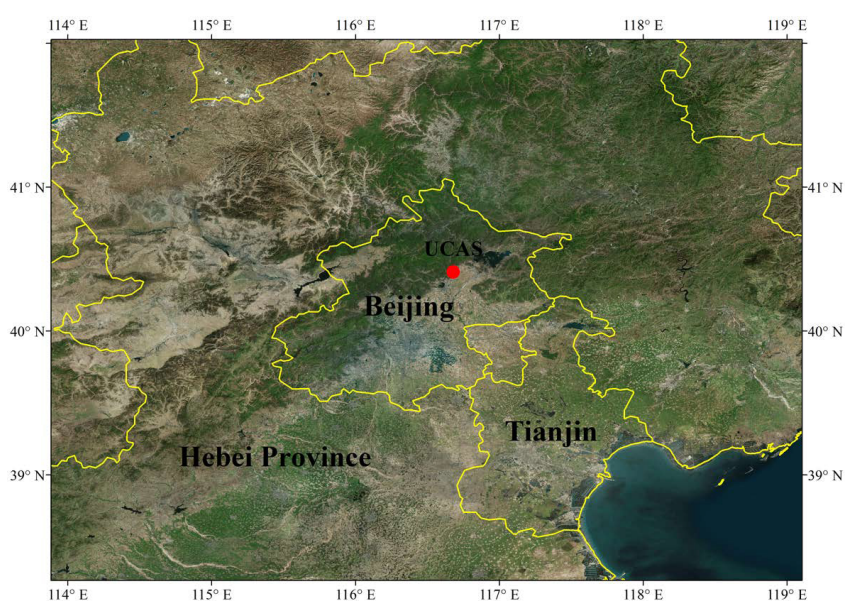

Figure 1. Location of the rural sampling site inside the campus of the University of Chinese Academy of Science (UCAS) in the north of Beijing.

lined stainless steel canisters. During field sampling, a model 910 canister sampler (Xonteck Inc., California, USA) with a constant flow rate of $66.7 \mathrm{~mL} \mathrm{~min}^{-1}$ was adopted to allow each canister to be filled in $60 \mathrm{~min}$. Samples were collected at approximately 10:00 and 15:00 local time (LT) on sunny days, and one or two more samples were collected at 12:00 and/or 18:00 LT on haze days when the visibility was less than $10 \mathrm{~km}$ at a relative humidity of less than $90 \%$ (Fu et al., 2016). A total of 153 samples were collected during sampling. According to the air pollution control measures, the field campaign was divided into periods I (25 October2 November), II (3-12 November) and III (13 November31 December). Period II was when temporary control measures (Table 1; http://www.zhb.gov.cn/gkml/hbb/qt/201411/ t20141115_291482.htm, last access: 8 May 2018) were implemented for better air quality. Wintertime heating started on 15 November just after the cease of temporary control measures on 13 November. During the sampling periods, the prevailing winds were mostly from north to northwest (315$360^{\circ}$ ); the average wind speeds were $3.5,3.9$ and $4.1 \mathrm{~m} \mathrm{~s}^{-1}$; and the average temperature was $11.4,7.0$ and $0.6^{\circ} \mathrm{C}$ during periods I, II and III, respectively.

\subsection{Laboratory analysis of VOCs and carbon monoxide}

All ambient air samples were analyzed with a model 7100 pre-concentrator (Entech Instruments, California, USA) coupled with an Agilent 5973N gas chromatography mass selective detector flame ionization detector (GC-MSD/FID, Agilent Technologies, USA). Detailed cryogenic concentration steps are described elsewhere (Y. L. Zhang et al., 2012). Briefly, $500 \mathrm{~mL}$ ambient air in the canister was first drawn through a primary liquid-nitrogen cryogenic trap with glass beads at $-160^{\circ} \mathrm{C}$ to tap VOCs. The primary trap was then heated to $10^{\circ} \mathrm{C}$, and all target compounds were transferred 
Table 1. Enhanced temporary air pollution control measures during the 2014 Asian-Pacific Economic Cooperation (APEC) summit.

\begin{tabular}{|c|c|c|}
\hline Control types & Details & Control areas \\
\hline Traffic & $\begin{array}{l}\text { Yellow-labeled vehicles were banned from inside the sixth ring } \\
\text { of Beijing and the Huairou urban area. } \\
\text { The number of private vehicles in operation was reduced by } \\
50 \% \text { through an odd-even license plate rule throughout Bei- } \\
\text { jing. } \\
\text { Trucks were limited inside the sixth ring of Beijing between } \\
6: 00 \text { and } 24: 00 \text { (UTC+8). } \\
\text { A total of } 70 \% \text { of government cars were also ordered off the } \\
\text { roads in Beijing. }\end{array}$ & $\begin{array}{l}\text { Inside the sixth ring of Beijing } \\
\text { and the Huairou urban area }\end{array}$ \\
\hline Industrial & $\begin{array}{l}\text { A total of } 9289 \text { enterprises were suspended; } 3900 \text { enterprises } \\
\text { were ordered to limit production. } \\
\text { More than } 40000 \text { construction sites were shut down. }\end{array}$ & $\begin{array}{l}\text { Beijing, some areas of Tianjin, } \\
\text { Hebei, Shanxi, Shandong and } \\
\text { Inner Mongolia }\end{array}$ \\
\hline Other fields & $\begin{array}{l}\text { Open fire was completely controlled in the North China Plain. } \\
\text { Road cleaning and water spraying in Beijing were increased. } \\
\text { Other related control measures were carried out in surrounding } \\
\text { areas. }\end{array}$ & $\begin{array}{l}\text { North China Plain } \\
\text { Tianjin, Hebei, Shanxi, Shan- } \\
\text { dong and Inner Mongolia }\end{array}$ \\
\hline
\end{tabular}

by pure helium to a secondary trap at $-50^{\circ} \mathrm{C}$ with TenaxTA as the adsorbent. The majority of $\mathrm{H}_{2} \mathrm{O}$ and $\mathrm{CO}_{2}$ was removed through these two traps. Then the secondary trap was heated to transfer VOCs by helium to a third cryofocus trap at $-170^{\circ} \mathrm{C}$. After the focusing step, the third trap was rapidly heated and the VOCs were transferred to the GC-MSD/FID system. The mixture was first separated by a DB-1 capillary column $(60 \mathrm{~m} \times 0.32 \mathrm{~mm} \times 1.0 \mu \mathrm{m}$, Agilent Technologies, USA) with helium as the carrier gas and then split in two ways, one with a PLOT-Q column $(30 \mathrm{~m} \times 0.32 \mathrm{~mm} \times 20.0 \mu \mathrm{m}$, Agilent Technologies, USA) followed by a FID detector, and the other with a $0.35 \mathrm{~m} \times 0.10 \mathrm{~mm}$ ID stainless steel line followed by MSD detection. The GC oven temperature was programmed to be initially at $10^{\circ} \mathrm{C}$, held constant for $3 \mathrm{~min}$, increased to $120^{\circ} \mathrm{C}$ at $5^{\circ} \mathrm{C} \mathrm{min}^{-1}$, and then at $10^{\circ} \mathrm{C} \mathrm{min}^{-1}$ to $250^{\circ} \mathrm{C}$ with a final holding time of $7 \mathrm{~min}$. The MSD was run in selected ion monitoring (SIM) mode and the ionization method was electron impacting. Carbon monoxide (CO) in the ambient air samples was analyzed with an Agilent model 6890 gas chromatograph equipped with a FID and a packed column $(5 \AA$ molecular sieve $60 / 80 \mathrm{mesh}, 3 \mathrm{~m} \times 0.32 \mathrm{~cm}$ ). CO was first separated by a packed column, then converted to $\mathrm{CH}_{4}$ by a Ni-based catalyst and finally detected by a FID (Z. Zhang et al., 2016).

\subsection{Quality control and quality assurance}

Before sampling, all canisters were flushed at least five times by repeatedly filling and evacuating humidified zero air. In order to check if there was any contamination in the canisters, all canisters were evacuated after the cleaning procedures, refilled with pure nitrogen, stored in the laboratory for at least
$24 \mathrm{~h}$ and then analyzed the same way as field samples to make sure that all the target VOCs were not present.

Target compounds were identified based on their retention times and mass spectra and were quantified using external calibration methods. The calibration standards were prepared by dynamically diluting the Photochemical Assessment Monitoring Station (PAMS) standard mixture and TO14 standard mixture (100 ppbv, Spectra Gases Inc., New Jersey, USA) to $0.5,1,5,15$ and $30 \mathrm{ppb}$. The calibration curves were obtained by running the five diluted standards plus humidified zero air the same way as the field samples. The humidified zero air was initially analyzed every day to ensure the cleanness of the system and then the analytical system was challenged daily with a one-point (typically $1 \mathrm{ppb}$ ) calibration before running air samples. If the responses were beyond $\pm 10 \%$ of the initial calibration curve, recalibration was performed. The method detection limits (MDLs) for each VOC species were presented in Table 2.

\subsection{Positive matrix factorization (PMF)}

PMF is a multivariate factor analysis tool that decomposes a matrix of sample data into two matrices: factor contributions $(G)$ and factor profiles $(F)$. The method is reviewed briefly here and described in greater detail elsewhere (Paatero and Tapper, 1994; Paatero, 1997). PMF uses both concentration and user-provided uncertainty associated with the data to weight individual points. Data values below the MDL were substituted with MDL/2; missing data values were substituted with median concentrations. If the concentration is less than or equal to the MDL provided, the uncertainty is calculated using the equation of Unc $=$ $5 / 6 \times \mathrm{MDL}$; if the concentration is greater than the MDL provided, the uncertainty is calculated as Unc $=[$ (error fac- 
Table 2. The mixing ratios, ranges and $95 \%$ confidence intervals (95\% C.I.) of VOCs during periods I, II and III at the rural site inside UCAS (in parts per trillion by volume, pptv).

\begin{tabular}{|c|c|c|c|c|c|c|c|}
\hline \multirow[t]{2}{*}{ Species } & \multirow[t]{2}{*}{$\mathrm{MDL}^{\mathrm{a}}$} & \multicolumn{2}{|c|}{ Period I } & \multicolumn{2}{|c|}{ Period II } & \multicolumn{2}{|c|}{ Period III } \\
\hline & & Range & Mean (95 \% C.I.) & Range & Mean (95 \% C.I.) & Range & Mean (95\% C.I.) \\
\hline Ethane & 39 & $1172-7855$ & $3254(743)$ & $910-5511$ & $2442(491)$ & $1082-12714$ & $3674(465)$ \\
\hline Propane & 31 & $427-6145$ & $2880(720)$ & $270-4138$ & $1296(384)$ & $598-7604$ & 2479 (329) \\
\hline$i$-Butane & 14 & $53-2755$ & $1121(312)$ & $59-1400$ & 474 (187) & $106-2741$ & 754 (129) \\
\hline$n$-Butane & 21 & $158-2947$ & $1283(302)$ & $83-1735$ & $562(196)$ & $174-3047$ & $841(136)$ \\
\hline$i$-Pentane & 14 & 94-3729 & $1425(354)$ & 39-1388 & $561(167)$ & $72-12590$ & $1018(279)$ \\
\hline$n$-Pentane & 8 & $47-1697$ & $615(182)$ & 30-910 & $247(106)$ & $26-4808$ & $456(112)$ \\
\hline 2,2-Dimethylbutane & 14 & $15-68$ & $30(6)$ & $17-32$ & $24(3)$ & $\mathrm{BDL}^{\mathrm{b}}-75$ & $26(2)$ \\
\hline Cyclopentane & 12 & $13-135$ & $64(15)$ & BDL-64 & $35(7)$ & $13-274$ & $50(8)$ \\
\hline 2,3-Dimethylbutane & 12 & $13-140$ & $45(15)$ & $22-51$ & $32(4)$ & $13-235$ & $38(6)$ \\
\hline 2-Methylpentane & 8 & $13-679$ & $171(68)$ & $12-257$ & $77(31)$ & $9-1077$ & $124(27)$ \\
\hline 3-Methylpentane & 7 & $12-548$ & $150(54)$ & $14-220$ & $68(26)$ & $16-792$ & $104(20)$ \\
\hline$n$-Hexane & 6 & $115-1033$ & $505(97)$ & $102-921$ & $324(89)$ & $108-7393$ & $1400(257)$ \\
\hline Methylcyclopentane & 9 & $10-283$ & $100(30)$ & $13-195$ & $59(23)$ & BDL-535 & $88(17)$ \\
\hline 2,4-Dimethylpentane & 4 & BDL-43 & $15(5)$ & BDL-15 & $10(2)$ & BDL-90 & $16(2)$ \\
\hline Cyclohexane & 6 & $10-458$ & $167(51)$ & $10-107$ & $43(14)$ & $7-646$ & $76(17)$ \\
\hline 2-Methylhexane & 6 & $10-304$ & $68(27)$ & $7-56$ & $22(6)$ & $7-318$ & $51(10)$ \\
\hline 2,3-Dimethylpentane & 9 & BDL-139 & $31(12)$ & BDL-24 & $15(2)$ & BDL-102 & $28(3)$ \\
\hline 3-Methylhexane & 6 & $12-436$ & $93(38)$ & $8-97$ & $41(11)$ & $9-367$ & $70(12)$ \\
\hline 2,2,4-Trimethylpentane & 9 & $12-126$ & $44(12)$ & BDL -41 & $25(4)$ & BDL-127 & $38(5)$ \\
\hline$n$-Heptane & 10 & $12-358$ & $89(33)$ & $12-71$ & $30(8)$ & $13-441$ & $82(14)$ \\
\hline Methylcyclohexane & 5 & BDL-162 & $51(17)$ & BDL-66 & $21(7)$ & BDL-162 & $44(8)$ \\
\hline 2,3,4-Trimethylpentane & 6 & BDL-38 & $14(4)$ & BDL-12 & $9(1)$ & BDL-59 & $16(2)$ \\
\hline 2-Methylheptane & 4 & $8-175$ & $31(16)$ & BDL-31 & $13(3)$ & BDL-91 & $22(3)$ \\
\hline 3-Methylheptane & 5 & BDL-231 & $26(20)$ & BDL-15 & $8(1)$ & BDL-74 & $17(2)$ \\
\hline$n$-Octane & 6 & $8-104$ & $42(11)$ & BDL-31 & $18(3)$ & BDL-160 & $40(6)$ \\
\hline$n$-Nonane & 6 & 9-99 & $40(11)$ & BDL-37 & $18(4)$ & BDL-171 & $38(6)$ \\
\hline$n$-Decane & 6 & 14-777 & $129(74)$ & $8-110$ & $36(14)$ & BDL-600 & $73(17)$ \\
\hline$n$-Undecane & 7 & $47-317$ & $151(35)$ & $27-206$ & $66(20)$ & $11-374$ & 94 (12) \\
\hline$n$-Dodecane & 7 & $9-646$ & $129(57)$ & $25-313$ & $75(30)$ & $8-316$ & $63(9)$ \\
\hline Ethylene & 41 & $367-3495$ & $1788(391)$ & $553-3572$ & $1254(352)$ & 319-13911 & $2313(428)$ \\
\hline Propene & 31 & $117-1264$ & 430 (118) & $170-766$ & $371(67)$ & $176-3222$ & $820(128)$ \\
\hline 1-Butene & 17 & $19-161$ & $107(18)$ & BDL-100 & $55(12)$ & $19-581$ & $137(22)$ \\
\hline 1,3-Butadiene & 20 & $21-403$ & $154(44)$ & $23-234$ & $79(27)$ & BDL-2140 & $252(74)$ \\
\hline trans-2-Butene & 5 & BDL-41 & $18(4)$ & BDL-35 & $12(4)$ & BDL-425 & $39(10)$ \\
\hline cis-2-Butene & 7 & $9-50$ & $23(4)$ & BDL-38 & $14(5)$ & BDL-276 & $37(7)$ \\
\hline 1-Pentene & 20 & BDL-47 & $33(3)$ & $21-25$ & $23(1)$ & BDL-127 & $52(6)$ \\
\hline Isoprene & 13 & BDL-623 & $163(56)$ & $16-143$ & $62(15)$ & $17-765$ & $200(24)$ \\
\hline trans-2-Pentene & 10 & BDL-37 & $17(4)$ & BDL-19 & $15(3)$ & BDL-65 & $23(3)$ \\
\hline cis-2-Pentene & 6 & BDL-24 & $11(3)$ & BDL-9 & $8(0)$ & BDL-46 & $15(2)$ \\
\hline 2-Methyl-2-butene & 12 & $13-50$ & $21(4)$ & $17-20$ & $18(1)$ & BDL-61 & $24(2)$ \\
\hline Benzene & 14 & $75-2695$ & $868(279)$ & $43-1465$ & $410(179)$ & $72-2916$ & 795 (151) \\
\hline Toluene & 9 & $120-3585$ & $1273(419)$ & $47-1186$ & $343(126)$ & $62-3425$ & 840 (146) \\
\hline Ethylbenzene & 6 & $25-2210$ & $684(240)$ & $12-611$ & $145(67)$ & $23-2450$ & $317(75)$ \\
\hline$m / p$-Xylene & 9 & $39-2106$ & $765(248)$ & $16-620$ & $149(67)$ & $25-3285$ & $422(91)$ \\
\hline Styrene & 8 & $15-578$ & $167(71)$ & BDL-99 & $32(11)$ & $10-1267$ & $151(38)$ \\
\hline$o$-Xylene & 4 & $11-965$ & 334 (104) & $9-284$ & $71(31)$ & $15-1224$ & $178(36)$ \\
\hline Isopropylbenzene & 4 & $5-66$ & $24(7)$ & BDL-21 & $11(2)$ & BDL-77 & $18(3)$ \\
\hline$n$-Propylbenzene & 4 & $6-231$ & $71(27)$ & BDL-55 & $20(7)$ & $5-239$ & $38(8)$ \\
\hline$m$-Ethyltoluene & 3 & $13-593$ & $136(67)$ & $4-91$ & $28(11)$ & $4-854$ & $85(23)$ \\
\hline$p$-Ethyltoluene & 3 & $6-295$ & $61(29)$ & $4-59$ & $17(6)$ & $4-245$ & $41(9)$ \\
\hline 1,3,5-Trimethylbenzene & 3 & $7-217$ & $48(21)$ & BDL-35 & $12(4)$ & $4-179$ & $38(6)$ \\
\hline$o$-Ethyltoluene & 3 & $5-246$ & $64(26)$ & $4-58$ & $17(6)$ & $5-230$ & $40(8)$ \\
\hline 1,2,4-Trimethylbenzene & 6 & 22-984 & $220(93)$ & $13-219$ & $58(22)$ & $8-803$ & $127(26)$ \\
\hline 1,2,3-Trimethylbenzene & 5 & $12-442$ & $82(37)$ & BDL-92 & $24(9)$ & $6-300$ & $56(11)$ \\
\hline 1,3-Diethylbenzene & 4 & $11-135$ & $35(12)$ & BDL-26 & $15(3)$ & BDL-126 & $26(4)$ \\
\hline 1,4-Diethylbenzene & 4 & $14-461$ & $80(40)$ & $5-69$ & $23(7)$ & BDL-292 & $51(10)$ \\
\hline 1,2-Diethylbenzene & 4 & BDL-30 & $15(4)$ & BDL-8 & $6(1)$ & BDL-76 & $15(2)$ \\
\hline Ethyne & 57 & $406-10539$ & $3128(1043)$ & $290-6260$ & $1625(615)$ & $584-10378$ & $3008(509)$ \\
\hline
\end{tabular}

${ }^{\mathrm{a}}$ MDL, method detection limit, pptv. ${ }^{\mathrm{b}}$ BDL, below detection limit. 
tion $\times$ mixing ratio $\left.)^{2}+(\mathrm{MDL})^{2}\right]^{1 / 2}$. The number of factors in PMF was initially chosen based on the results of the Principal Component Analysis/Absolute Principal Component Scores (PCA/APCS) model (Y. L. Zhang et al., 2012).

\section{Results and discussion}

\subsection{Changing mixing ratios and compositions}

As mentioned above, during period II (3-12 November), temporary emission control measures were implemented to improve air quality during the 2014 APEC summit. The total mixing ratio of VOCs observed at the rural site at UCAS during period II was $11.25 \pm 3.22 \mathrm{ppb}$ on average, significantly lower than the value of $23.41 \pm 5.76 \mathrm{ppb}$ during period I and $21.71 \pm 2.97 \mathrm{ppb}$ during period III (Fig. 2). These levels were less than half the values $(57.45,36.17$ and $56.56 \mathrm{ppb}) \mathrm{ob}-$ served by $\mathrm{Li}$ et al. (2015) at an urban site in Beijing before, during and after the APEC summit, respectively. However, our measurements at a rural site in this study and the measurements at an urban site by Li et al. (2015) consistently demonstrated that the temporary emission controls resulted in a large decrease in ambient VOCs during the APEC summit, with a more than $30 \%$ reduction in urban areas (Li et al., 2015) and an approximately $50 \%$ reduction in rural areas, as observed in this study. These reduced ambient mixing ratios of VOCs during period II were also in line with the decreased $\mathrm{PM}_{2.5}$ concentrations observed in Beijing during the APEC summit (J. G. Liu et al., 2015) and the reduced $\mathrm{NO}_{2}$ vertical column density (VCD) and aerosol optical depth (AOD) in Beijing during the APEC summit based on remote sensing (Huang et al., 2015).

The percentages of alkanes, alkenes and ethyne in total VOCs were similar: alkanes accounted for $54 \%, 57 \%$ and $54 \%$ of VOCs; alkenes accounted for $12 \%, 16 \%$ and $17 \%$; and ethyne accounted for $13 \%, 14 \%$ and $14 \%$ of VOCs during periods I, II and III, respectively. The percentage of aromatics was lower during period II (12\%) than during period I $(21 \%)$ and period III $(15 \%)$.

The mean mixing ratios of alkanes, alkenes, aromatics and ethyne during period II were $6.47,1.83,1.33$ and $1.62 \mathrm{ppb}$ (Fig. 2), and they were $49.0 \%, 32.5 \%, 72.8 \%$ and $48.1 \%$ lower than those during period I, respectively. Aromatics evidently underwent a more substantial decrease. Benzene, toluene, ethylbenzene and $m, p$-xylene, which are the most abundant aromatics and usually collectively termed BTEX, were $52.8 \%, 73.1 \%, 78.8 \%$ and $80.5 \%$ lower during period II than during period I, respectively.

Table S1 in the Supplement shows a comparison of VOCs from our study with those observed at other metropolitan areas in the world. Mixing ratios of VOCs from this study at a rural site in Beijing during period I (23.41 ppb) and period III (21.71 ppbv) were comparable to those in urban Shanghai from January 2007 to March 2010 (Cai et al., 2010) but lower than those in Beijing during June 2008 (B. Wang et al., 2010), Guangzhou from June 2011 to May 2012 (Zou et al., 2015), Lille, France, from May 1997 to April 1999 (Borbon et al., 2002) and Houston in August-September 2006 (Leuchner and Rappenglück, 2010). Average mixing ratios of VOCs during period II (11.25 ppbv) with enhanced emission control in the present study were significantly lower than those reported in other metropolitan areas. As for the most abundant VOC species including ethane, propane, ethylene, benzene, toluene and ethyne, the mixing ratios of ethane and ethylene at UCAS were similar to those at Beijing during June 2008 (B. Wang et al., 2010) and urban Guangzhou from June 2011 to May 2012 (Zou et al., 2015) but significantly lower than those in urban Beijing during 2014 APEC (Li et al., 2015). Mixing ratios of propane in the present study are comparable to those in Hong Kong from September 2002 to August 2003 (Guo et al., 2007) and Lille, France, from May 1997 to April 1999 (Borbon et al., 2002), but factors of 2-3 lower than those reported in urban Shanghai from January 2007 to March 2010 (Cai et al., 2010) and Guangzhou from June 2011 to May 2012 (Zou et al., 2015). Mixing ratios of benzene and toluene in Lille, France, from May 1997 to April 1999 (Borbon et al., 2002) were over 2 times higher than those in the present study. Mixing ratios of ethylene, benzene and toluene in the present study were comparable to those observed in Houston during August-September 2006 (Leuchner and Rappenglück, 2010); meanwhile, ethyne, a tracer of incomplete combustion, had mixing ratios 3-4 times higher than those in Houston.

The total ozone formation potential (OFP), based on the simplified approach of MIR (maximum incremental reactivity) scale (Carter, 2009), on average was 60.64, 28.51 and $61.47 \mathrm{ppb}$ (Table S2) during periods I, II and III, respectively, with a $53.0 \%$ reduction during period II relative to period I (Fig. 2). The SOA formation potential (SOAFP) under high$\mathrm{NO}_{x}$ and low- $\mathrm{NO}_{x}$ conditions (Ng et al., 2007; Lim and Ziemann, 2009) was also calculated (Table S3). As shown in Fig. 2, the total SOAFP under low- $\mathrm{NO}_{x}$ conditions decreased by $71.0 \%$ from $8.77 \mu \mathrm{g} \mathrm{m}^{-3}$ during period I to $2.54 \mu \mathrm{g} \mathrm{m}^{-3}$ during period II, and the total SOAFP under high- $\mathrm{NO}_{x}$ conditions decreased by $64.4 \%$ from $4.02 \mu \mathrm{g} \mathrm{m}^{-3}$ during period I to $1.43 \mu \mathrm{g} \mathrm{m}^{-3}$ during period II. This significant decrease in OFP and SOAFP during period II is related to lowered VOC mixing ratios, especially larger decreases in reactive alkenes and aromatics: alkenes and aromatics explain $26 \%$ and $52 \%$ of the reduction in total OFP, respectively, while the decrease in total SOAFP is mostly due to the altered contribution of aromatics (Table S3), whose SOAFP decreased from $7.30 \mu \mathrm{g} \mathrm{m}^{-3}$ during period I to $1.93 \mu \mathrm{g} \mathrm{m}^{-3}$ during period II under low- $\mathrm{NO}_{x}$ conditions and from $2.39 \mu \mathrm{g} \mathrm{m}^{-3}$ during period I to $0.75 \mu \mathrm{g} \mathrm{m}^{-3}$ during period II under high- $\mathrm{NO}_{x}$ conditions. The results suggest that enhancing the emission control of reactive alkenes and aromatics would be more effective for reducing OFPs and SOAFPs of ambient VOCs. 


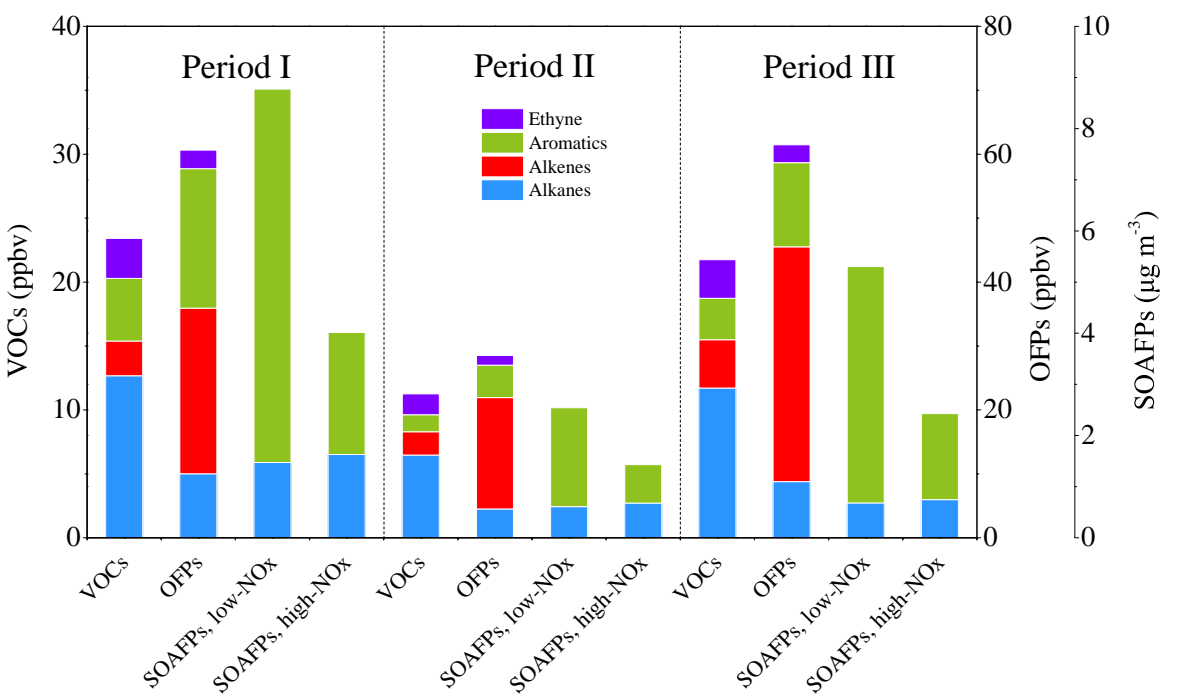

Figure 2. Mixing ratios of VOCs, ozone formation potentials (OFPs) and secondary organic aerosol formation potentials (SOAFPs) of ambient VOCs during periods I, II and III at UCAS.

\subsection{Pollution episodes and influence of source regions}

As shown in Fig. 3d and e, a number of episodes, such as those on 4-5 November, 15-16 November, 18-21 November, 28-30 November, 17 December and 26-28 December, with mixing ratios of VOCs over $30 \mathrm{ppb}$ were recorded along with an increase in the $\mathrm{CO}$ and $\mathrm{SO}_{2}$ concentrations (Fig. 3d) during the campaign. During the episode on 35 November, for example, the total mixing ratio of VOCs was $14.30 \mathrm{ppb}$ on 3 November, reached $31.96 \mathrm{ppb}$ on 4 November and then decreased again to $13.83 \mathrm{ppb}$ on 5 November. As shown in Fig. 3a, the wind speeds were all below $2 \mathrm{~m} \mathrm{~s}^{-1}$ during 3-5 November, and the planetary boundary layer (PBL) height on 4 November $(477 \mathrm{~m})$ was approximately $83 \%$ of that on 3 November $(578 \mathrm{~m}$ ) (Fig. 3c). This lower PBL height on 4 November could only partly explain the higher levels of VOCs. Figure S2a shows the $72 \mathrm{~h}$ back trajectories (HYSPLIT, v4.0; http://www.arl.noaa.gov/ready/ hysplit4.html, last access: 24 August 2018) of air masses from 3 to 5 November at a height of $100 \mathrm{~m}$ in $12 \mathrm{~h}$ intervals and the corresponding mixing ratios of VOCs. It demonstrated that the mixing ratios of VOCs increased rapidly while air masses changed from northerly to southerly and then declined sharply while the air masses turned back from southerly to northerly. The southern areas of UCAS are in central Beijing where emissions are stronger; consequently, air masses that passed through these areas would carry higher levels of pollutants to the sampling site, leading to the quick increase in the mixing ratios of VOCs. This rapid change in source regions could reasonably explain more than the PBL height during the pollution episode of VOCs. As shown in Figs. S2b, 2c and d, back trajectories also suggested that the episodes on 18-21 November, 28-30 November and 2628 December are related to the altered source regions.

According to the $72 \mathrm{~h}$ back trajectories, air masses arriving at the sampling site could be categorized into two types (Fig. 4): (1) southerly (S) air masses, which passed through Hebei, Shandong, Tianjin and central Beijing with highdensity emissions before reaching UCAS, and (2) northerly (N) air masses, which originated from Mongolia and quickly passed through areas with less anthropogenic activity and low-density emissions before reaching UCAS. The pollution episodes with higher mixing ratios of VOCs and $\mathrm{CO}$, including the cases on 26-30 October, 4-5 November, 1516 November, 18-20 November, 25-26 November and 2628 December (Fig. 3d and e), all occurred under the influence of southerly air masses, also suggesting the impacts of emissions in the south.

During periods I, II and III, the average mixing ratios of VOCs for southerly air masses were 2.3, 2.3 and 2.9 times those for northerly air masses (Fig. 4), respectively; the OFPs in southerly air masses were 2.0, 2.0 and 3.3 times those in northerly air masses, respectively; and the SOAFPs in air masses from the south were 1.7, 3.3 and 3.7 times those in air masses from the north under low- $\mathrm{NO}_{x}$ conditions and 1.9, 2.7 and 3.5 times those in air masses from the north under high- $\mathrm{NO}_{x}$ conditions, respectively. These results indicate that the northern and southern regions are completely different in their source strengths. Stricter control measures in the southern region would be an effective way of abating VOC pollution in Beijing.

As mentioned above, the mixing ratios of VOCs, as well as their OFP and SOAFP, decreased greatly during period II. The changes in the southerly and northerly air masses indicate the changes in emissions from different source re- 


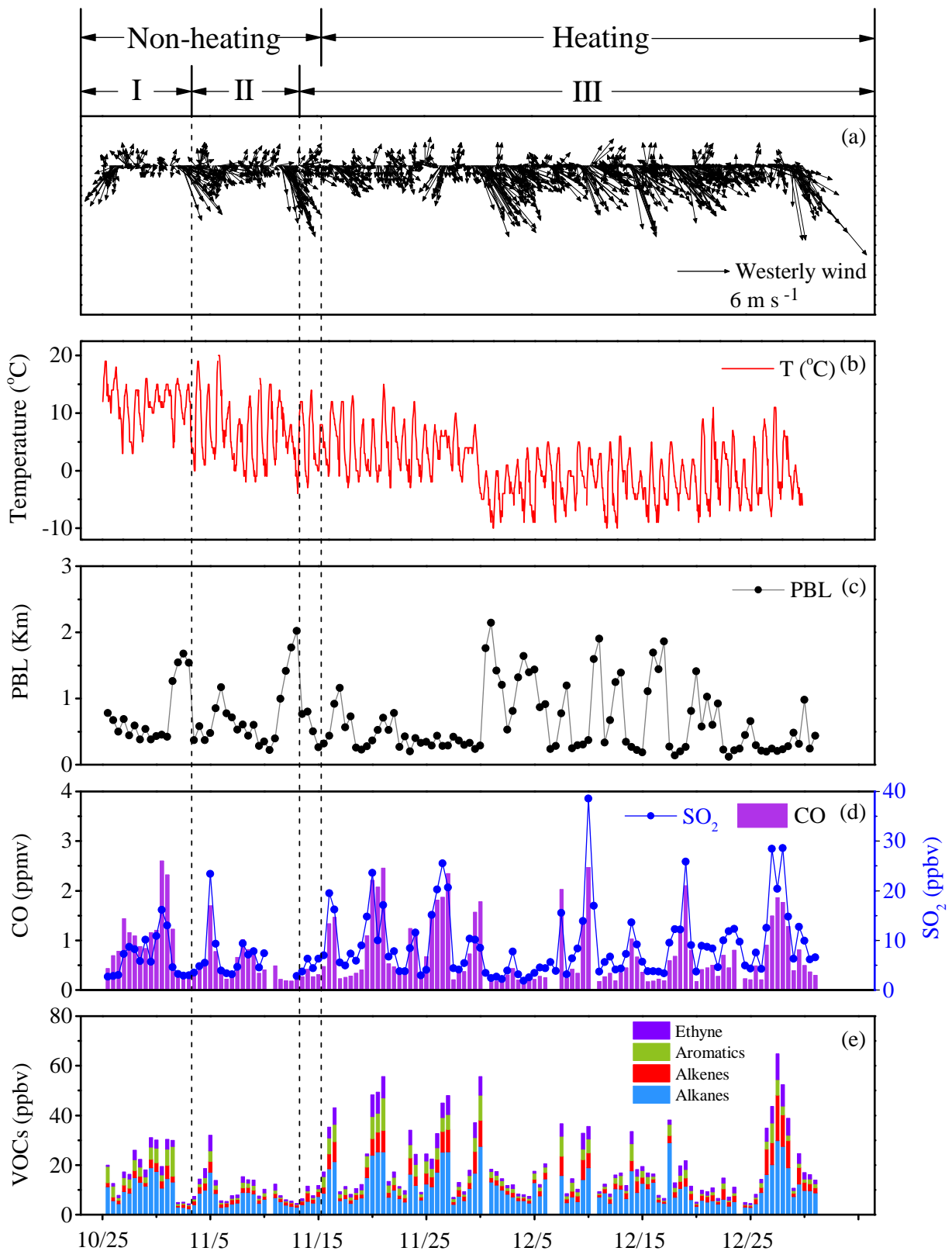

Figure 3. Time series of (a) wind speed and wind direction, (b) temperature, (c) planetary boundary layer height, (d) mixing ratios of $\mathrm{CO}$ and $\mathrm{SO}_{2}$, and (e) mixing ratios of VOCs at the sampling site inside UCAS. The heating periods started on 15 November. Period I: 25 October-2 November; period II: 3-12 November; period III: 13 November-31 December.

gions. In the southerly air masses, compared to those during period I, the average mixing ratios of alkanes, alkenes, aromatics and ethyne during period II were $8.32,2.16,1.93$ and $2.23 \mathrm{ppb}$, with reduction rates of $46.0 \%, 33.3 \%, 64.3 \%$ and $44.7 \%$, respectively; accordingly, the OFP decreased by $48.1 \%$ and the SOAFP decreased by $63.5 \%$ (low- $\mathrm{NO}_{x}$ conditions) and $57.6 \%$ (high- $\mathrm{NO}_{x}$ conditions) during period II compared to that during period I (Fig. 4). In the northerly air masses, the average mixing ratios of alkanes, alkenes, aromatics and ethyne decreased $37.7 \%, 4.8 \%, 87.0 \%$, and
$18.4 \%$ during period II compared to those during period I, respectively; the OFP decreased by $48.9 \%$ and SOAFP decreased by over $70 \%$ during period II relative to that in period I (Fig. 4). As discussed below, a more drastic decrease in aromatics in both the northerly and southerly air masses implied more effective control over emissions from industrial solvent use during the APEC summit, and the much fewer changes in the mixing ratios of alkenes in the northerly air masses were related to the less effective control over domestic coal/biomass burning in the northern regions. The mix- 
(a)
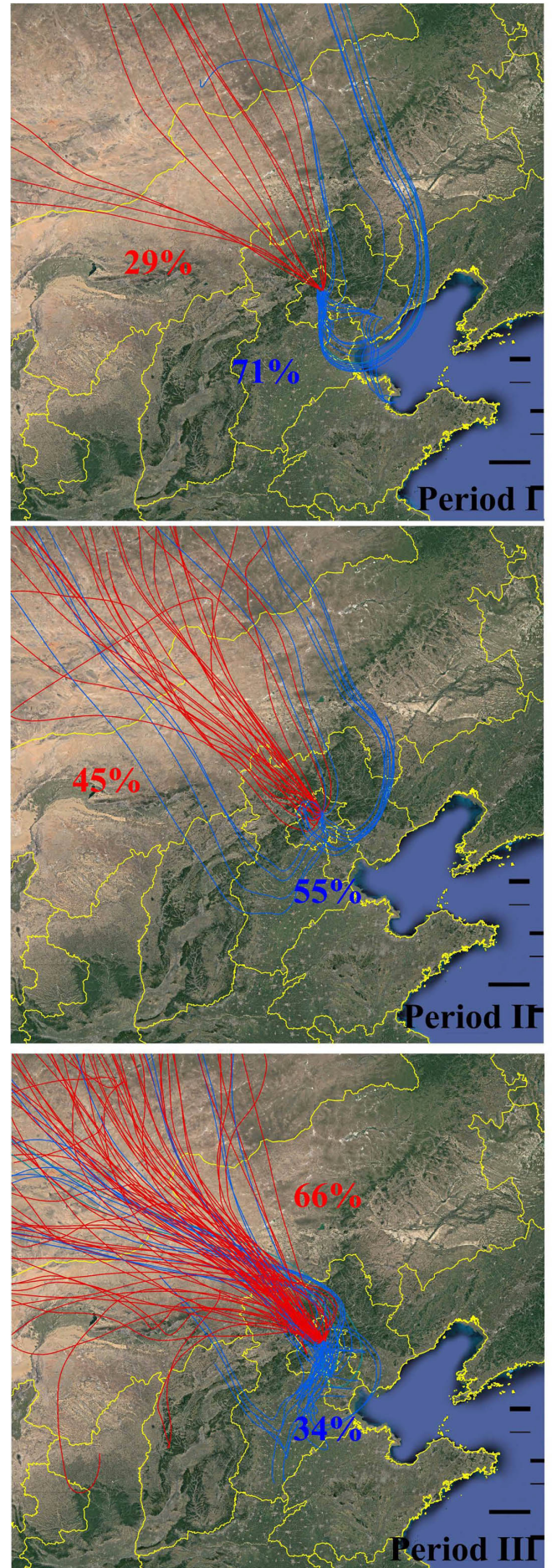

(b)
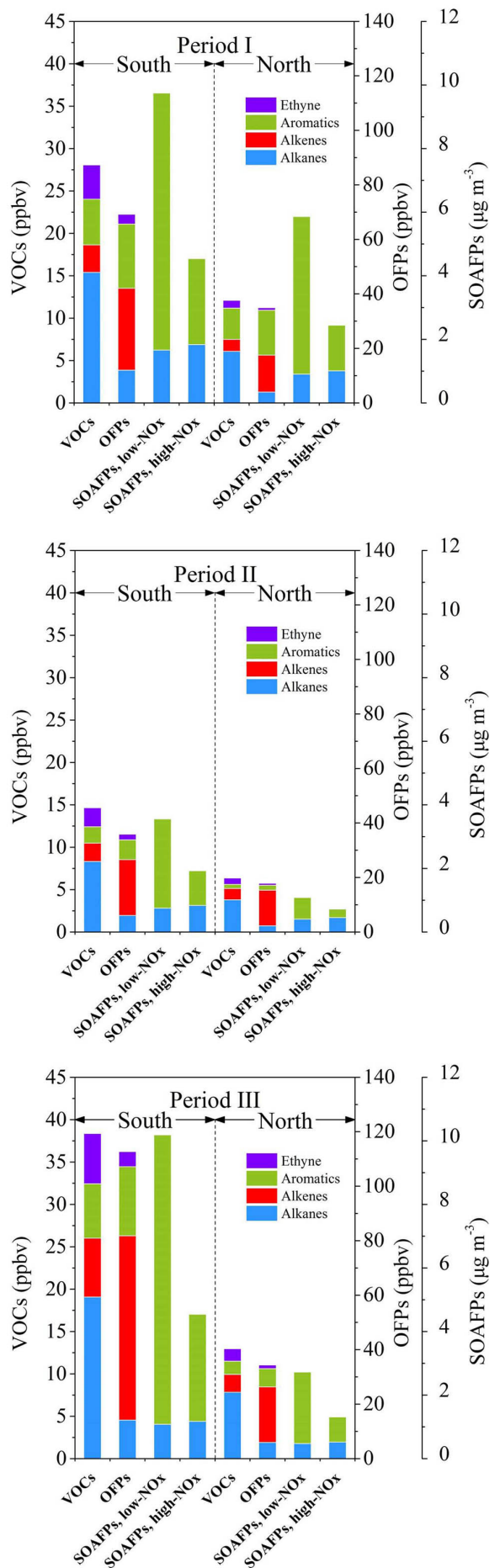

Figure 4. Mixing ratios of VOCs, ozone formation potentials (OFPs) and secondary organic aerosol formation potentials (SOAFPs) of VOCs in the air masses from the southern and northern regions (b) and corresponding back trajectories at $100 \mathrm{~m}$ above the ground level during periods I, II and III (a). 
ing ratios of VOCs in the southerly and northerly air masses during period III were $36.1 \%$ and $7.2 \%$ higher than those during period I, respectively. These different increase rates might be explained by the fact that the urban areas in the south were largely central heating areas where heat sources were only available after 15 November and the northern areas were largely rural areas where individual household heating might have started during period I.

\subsection{Source attribution and apportionment}

\subsubsection{Indication from tracers}

The great changes in the mixing ratios of VOCs during the campaign might have resulted from the altered contributions from emission sources, such as enhanced emission control during the APEC summit or intensified emissions due to wintertime heating. These changes could be indicated by the characteristic fingerprints of different sources (Guo et al., 2007).

The toluene / benzene ( $\mathrm{T} / \mathrm{B}$ ) ratio, a widely used indicator for sources of aromatics, was $1.09,0.67$ and 0.70 on average during periods I, II and III, respectively (Fig. S3a). While the $\mathrm{T} / \mathrm{B}$ ratios during periods II and III approached 0.6 , which is characteristic of coal/biomass burning (Liu et al., 2008; K. K. Liu et al., 2015), the ratios during period I fell between those of coal/biomass burning (0.6) and vehicle exhaust (1.6) (Wang et al., 2002; Liu et al., 2009; Y. L. Zhang et al., 2013a). Carbon monoxide (CO), a typical tracer of the incomplete combustion of biomass or fossil fuels (Parrish et al., 2009; Z. Zhang et al., 2015), showed highly significant correlations with benzene during period II $\left(r^{2}=0.96\right.$, Fig. S3b) and period III ( $r^{2}=0.88$, Fig. S3b). $\mathrm{SO}_{2}$, a good indicator of coal burning ( $\mathrm{Li}$ et al., 2017), had similar concentrations during period II and period I, but its concentration increased $56.5 \%$ on average during period III compared to that during period I (Fig. 3d), suggesting an increased contribution of coal burning after the start of central heating. Methyl tertbutyl ether (MTBE), a specific indicator of gasoline-related traffic emissions (Song et al., 2007; Cai et al., 2010), showed better correlation with benzene during period I $\left(r^{2}=0.88\right.$, Fig. S3c) than during periods II and III.

As toluene, ethylbenzene and xylene (TEX) mainly originate from solvent used in paint, decorations and coatings (Guo et al., 2007; Y. L. Zhang et al., 2012), the ratios of TEX to $\mathrm{CO}$ are widely used to examine the impact of solvent use relative to combustion emissions (Y. L. Zhang et al., 2013a). The ratios of $\mathrm{T} / \mathrm{CO}, \mathrm{E} / \mathrm{CO}$ and $\mathrm{X} / \mathrm{CO}$ were $0.61 \pm 0.09$, $0.23 \pm 0.06$ and $0.35 \pm 0.07\left(\mathrm{ppb} \mathrm{ppm}^{-1}\right)$ during period II, obviously lower than the values of $1.16 \pm 0.49,0.59 \pm 0.24$ and $0.99 \pm 0.41$ during period $\mathrm{I}$ and of $1.34 \pm 0.27,0.40 \pm 0.06$ and $0.83 \pm 0.09$ during period III (Fig. 5b), respectively. This decrease in the ratios of aromatics to $\mathrm{CO}$ during period II also reflected more effective control over solvent use during the APEC summit.
If further categorized according to the air mass trajectories, the ratios of $\mathrm{T} / \mathrm{CO}, \mathrm{E} / \mathrm{CO}$ and $\mathrm{X} / \mathrm{CO}$ decreased $29.5 \%, 45.7 \%$ and $45.7 \%$ in the southerly air masses during period II relative to those in period I and decreased $68.0 \%$, $80.3 \%$ and $83.0 \%$ in the northerly air masses during period II relative to those in period I, respectively (Fig. 5a). A larger decrease in the TEX / CO ratios in northerly air masses reflects the fact that the control of solvent use was more effective in northern regions.

\subsubsection{Source apportionment by PMF}

The 35 most abundant VOCs, including alkanes, alkenes, aromatics and ethyne, and source tracers, such as chloromethane, trichloroethylene, tetrachloroethylene and MTBE, plus $\mathrm{SO}_{2}$ and $\mathrm{CO}$, were selected for use with the PMF receptor model. Figure 6 shows the five sources retrieved by the model.

Factor 1 has high values of MTBE and $\mathrm{C}_{5}-\mathrm{C}_{6}$ alkanes. MTBE is a common gasoline additive in China, and 2,2dimethylbutane is used to enhance the octane levels of gasoline (Chang et al., 2004; Song et al., 2007; Cai et al., 2010). Ethyne can be formed during fuel combustion (Blake and Rowland, 1995; Song et al., 2007; Suthawaree et al., 2010). $\mathrm{C}_{5}-\mathrm{C}_{6}$ alkanes are associated with unburned vehicular emissions (Guo et al., 2004; Cai et al., 2010; Y. L. Zhang et al., 2013 b). Consequently factor 1 is related to gasoline vehicle emissions.

Factor 2 is distinguished by a strong presence of trichloroethylene and tetrachloroethylene and moderate contributions by propene and butenes. Trichloroethylene and tetrachloroethylene are species from industrial manufacturing (Yuan et al., 2013; Y. L. Zhang et al., 2015); propene and butenes are gases widely used in industry to prepare organic chemicals (Guo et al., 2007), such as during the production of synthetic rubber in the petrochemical industry (Lau et al., 2010). Thus, factor 2 was identified as industrial emissions.

Factor 3 accounts for larger percentages of toluene, ethylbenzene, $m / p$-xylene and $o$-xylene. TEX is known to be the primary constituent of solvent (Guo et al., 2004; Yuan et al., 2009; Zheng et al., 2013; J. K. Zhang et al., 2014a; Ou et al., 2015). These compounds are also the main components in emissions from automobile factories, paint and building coatings (Liu et al., 2008; Yuan et al., 2010). Therefore, this source is considered to be solvent use related to painting and building construction.

Factor 4 is diesel exhaust, which is characterized by a significant amount of $n$-undecane and $n$-dodecane (Song et al., 2007; Y. L. Zhang et al., 2012).

Factor 5 is characterized by the presence of ethane, ethylene, $\mathrm{CO}, \mathrm{SO}_{2}$ and chloromethane. Chloromethane is the typical tracer of biomass burning (Liu et al., 2008; Cai et al., 2010; J. K. Zhang et al., 2014a). Ethylene, ethane and propene are the top three species emitted during rice straw burning (Y. S. Zhang et al., 2013; Fang et al., 2017). The 

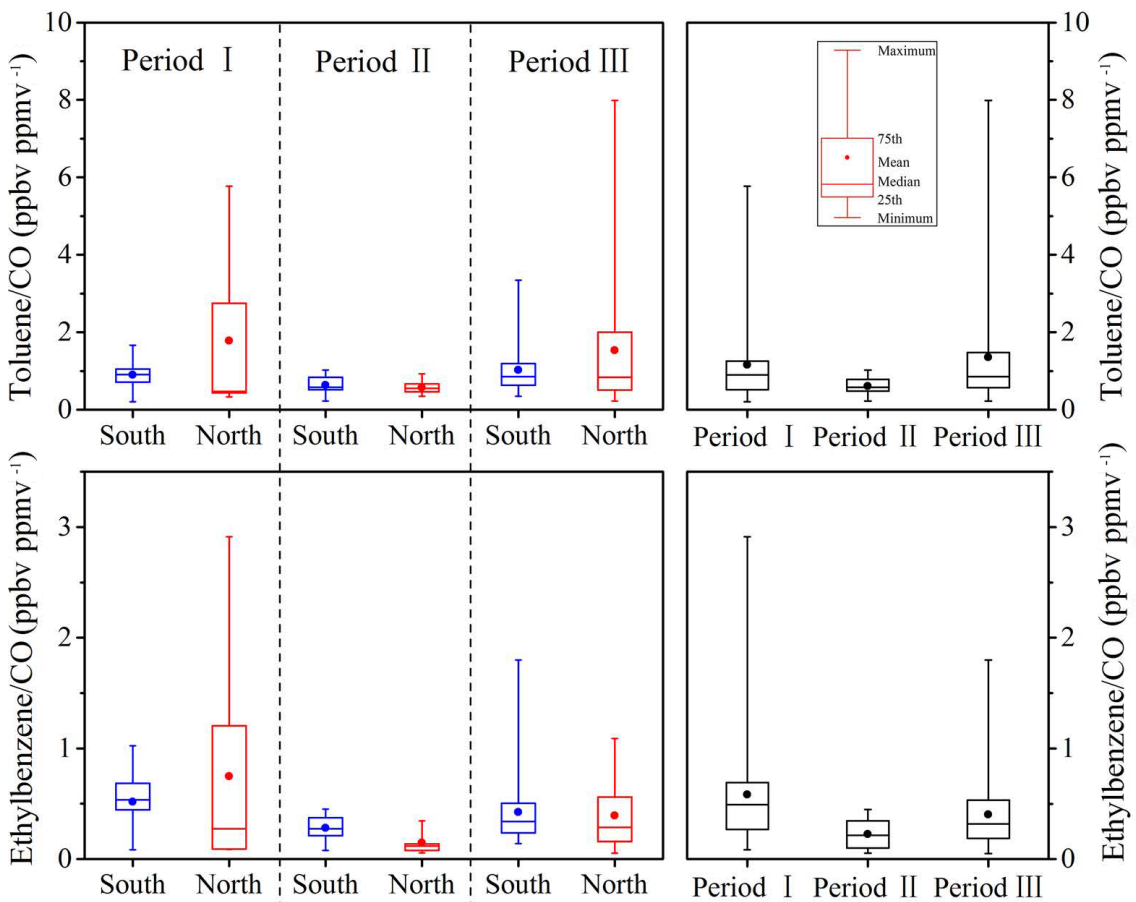

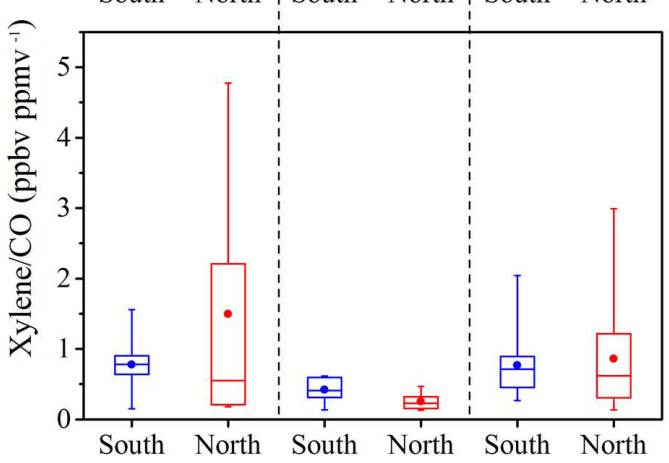

(a)

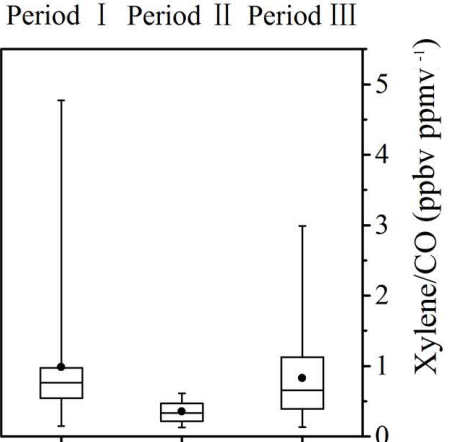

Period I Period II Period III

(b)

Figure 5. Ratios of aromatic hydrocarbons to carbon monoxide (CO) (a) in the air masses from the southern and northern regions and (b) in all samples during periods I, II and III. The lower and upper boundaries of the box represent the 25th and 75th percentiles, respectively; the whiskers below and above the box indicate the minimum and maximum, respectively; the line within the box marks the median; the dot represents the mean.

VOC species from coal burning are mainly ethyne, $\mathrm{C}_{2}-\mathrm{C}_{3}$ alkenes and alkanes, and aromatics such as benzene (Liu et al., 2008). $\mathrm{SO}_{2}$ is mainly from coal burning (Li et al., 2017). Thus, factor 5 is related to coal/biomass burning.

Figure 7 shows the source contributions during periods I, II and III. During period I, gasoline exhaust was the largest source and accounted for $24.0 \%$ of the VOCs, while during period II, coal/biomass burning became the largest source. The most significant changes due to the temporary emission control during period II were in the contribution percentages of coal/biomass burning $(22.3 \%$ in period $\mathrm{I}$ and $42.4 \%$ in period II) and solvent use (21.9\% in period I and $5.8 \%$ in period II). The large decrease in the contribution from sol- vent use was consistent with the above discussion about the TEX / CO ratios.

In period III (13 November-31 December), with central heating starting on 15 November, coal/biomass burning became the largest source $(45.1 \%)$, and industrial emission, solvent use, diesel exhaust and gasoline exhaust accounted for $25.2 \%, 12.8 \%, 8.7 \%$ and $8.2 \%$ of the VOCs, respectively. The time series of source contributions during the campaign are shown in Fig. S4; the contribution percentage of coal/biomass burning increased gradually with the increase in wintertime heating, while that of gasoline exhaust decreased.

Coal/biomass burning was an important source of VOCs during winter in Beijing, especially during period III with 


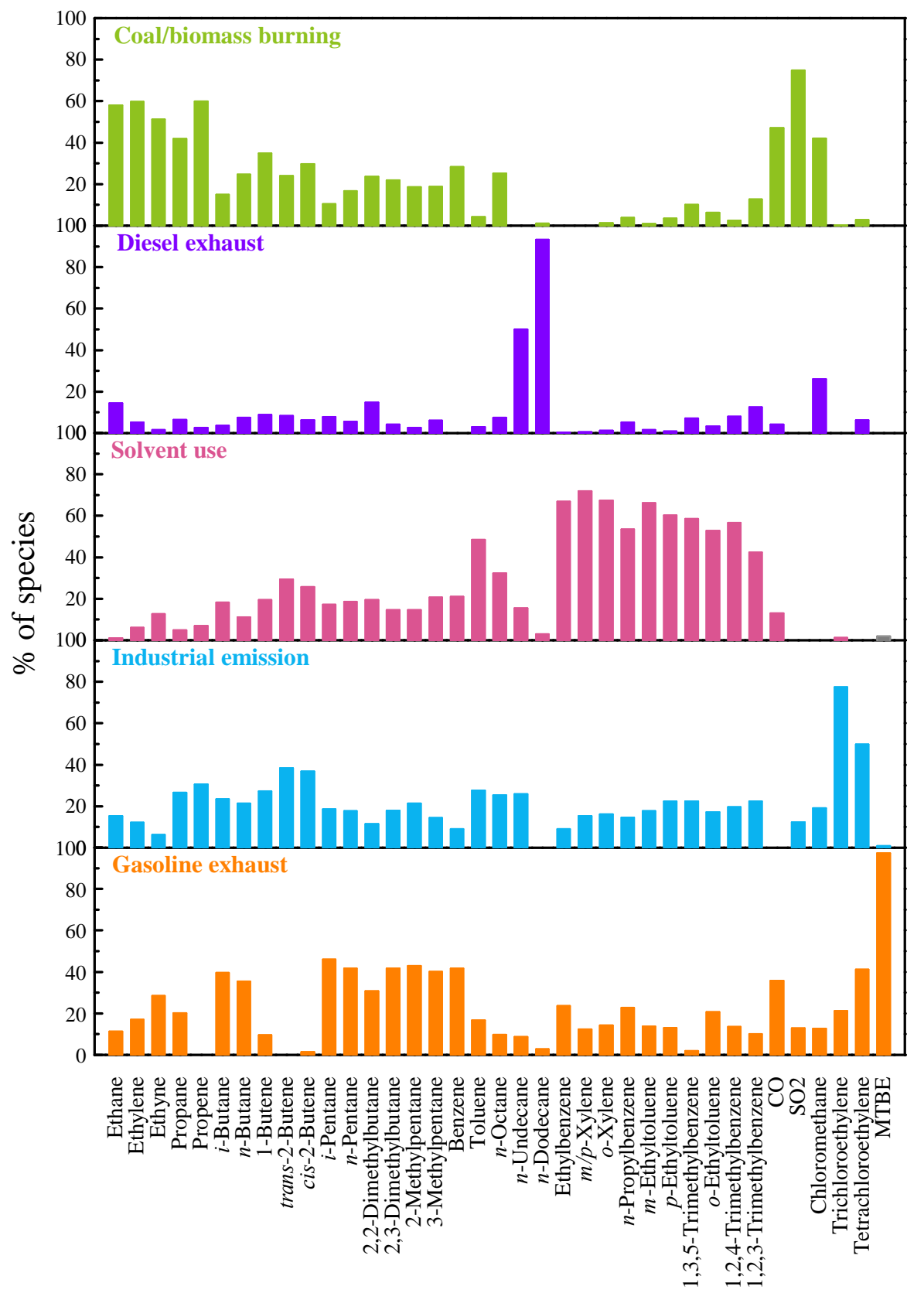

Figure 6. Source profiles resolved by PMF.

the start of central heating. In Beijing, coal consumption was greater than that of residential biomass (Liu et al., 2016). Coal is consumed in the residential, industrial and power sectors in Beijing. As shown in Fig. S5a, while annual total coal consumption dropped rapidly during 2006-2015, the annual residential coal consumption remained almost unchanged with its percentage of total coal consumption rising from $8.7 \%$ in 2006 to $23.4 \%$ in 2015 (Beijing Municipal Bureau of Statistics, 2016; Yu et al., 2018). As a matter of fact, over $60 \%$ of the residential coal consumption occurred in rural areas of Beijing (Fig. S5b), and residential coal is mainly burned in the winter season for heating houses (Xue et al., 2016). While emission factors of VOCs from residential coal burning have been found to be a factor of 20 greater than those from coal-fired power plants (Liu et al., 2017), the differences in coal quality between the urban and rural areas augment emissions in rural areas: coal used in the urban area was entirely anthracite with comparatively much lower emissions of volatiles than other types of coal (Xu et al., 2017); instead only $5-15 \%$ of coal used in rural areas was anthracite 


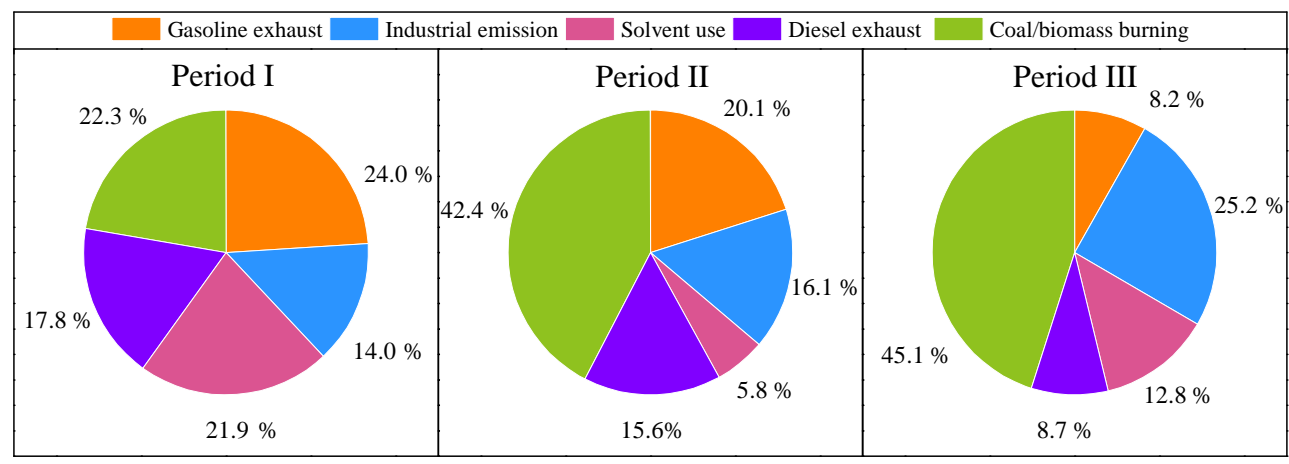

Figure 7. Contributions to VOCs from different sources during periods I, II and III as a percentage (\%).
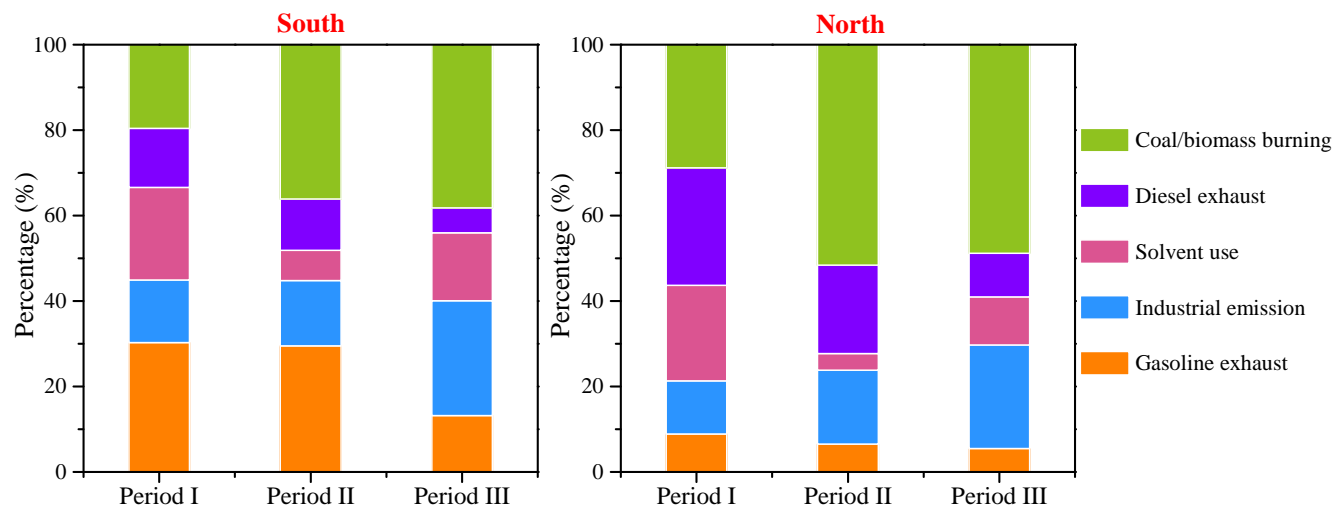

Figure 8. Source contributions (\%) to VOCs in the air masses from the southern and northern regions during periods I, II and III.

(Xue et al., 2016). Consequently, residential coal combustion could have been a major contributor to the ambient VOCs in rural areas of Beijing during winter.

Compared with that in period I (Fig. S6), the contribution from solvent use during period II was reduced to a greater extent than other sources; it became $4.29 \mathrm{ppb}$ lower and could explain $37.6 \%$ of the reduction in ambient VOCs (Table S4). The contribution from gasoline vehicles was $3.18 \mathrm{ppb}$ lower and accounted for $27.9 \%$ of the total reductions. The contribution from diesel exhaust and industrial emissions decreased 2.28 and $1.35 \mathrm{ppb}$ and explained $20.0 \%$ and $11.8 \%$ of the total reduction, respectively. Coal/biomass burning made similar contributions during periods I and II, with an elevated contribution percentage in period II due to the reduction in other sources. This is consistent with the fact that during the APEC summit residential coal/biomass burning was not restricted in the rural areas. Traffic-related sources (gasoline and diesel vehicles) and solvent use accounted for $47.9 \%$ and $37.6 \%$ of the total reduction in ambient VOCs, indicating that control measures (Table 1) related to the control of traffic and solvent use were among the most effective ways to reduce ambient VOCs.

Figure 8 shows the source contributions in the southerly and northerly air masses during periods I, II and III. In the southerly air masses, traffic-related emissions (gasoline and diesel vehicles) were the largest source, contributing $44.1 \%$ and $41.5 \%$ of the VOCs during periods I and II, respectively, while coal/biomass burning was the largest source during period III, contributing $38.2 \%$ of the VOCs. In the northerly air masses, coal/biomass burning contributed $28.8 \%, 51.6 \%$ and $48.8 \%$ of the VOCs during periods I, II and III, respectively. Overall, gasoline vehicle exhaust contributed more VOCs in the southern regions (mostly densely populated urban areas) and coal/biomass burning and diesel exhaust accounted for more emissions of VOCs in the northern regions (mostly rural areas). The contributions of different sources to most reactive alkenes and aromatics based on PMF were presented in Fig. 9. Alkenes mainly originated from coal/biomass burning, with shares of 31.2-68.0\%, and gasoline exhaust ranked second, with contributions of 3.0 $26.5 \%$. Unlike alkenes, aromatics were mainly from solvent use, accounting for $77.5 \%$ during period I and $29.0 \%$ during period II in the northerly air masses; gasoline exhaust contributed $8.2-43.6 \%$ of the aromatics during the campaign. In the southerly air masses, the reductions in solvent use, gasoline exhaust and diesel exhaust during period II relative to period I could explain $38.1 \%, 31.1 \%$ and $15.8 \%$ of the total reduction in VOCs, respectively. In the northerly air masses, 

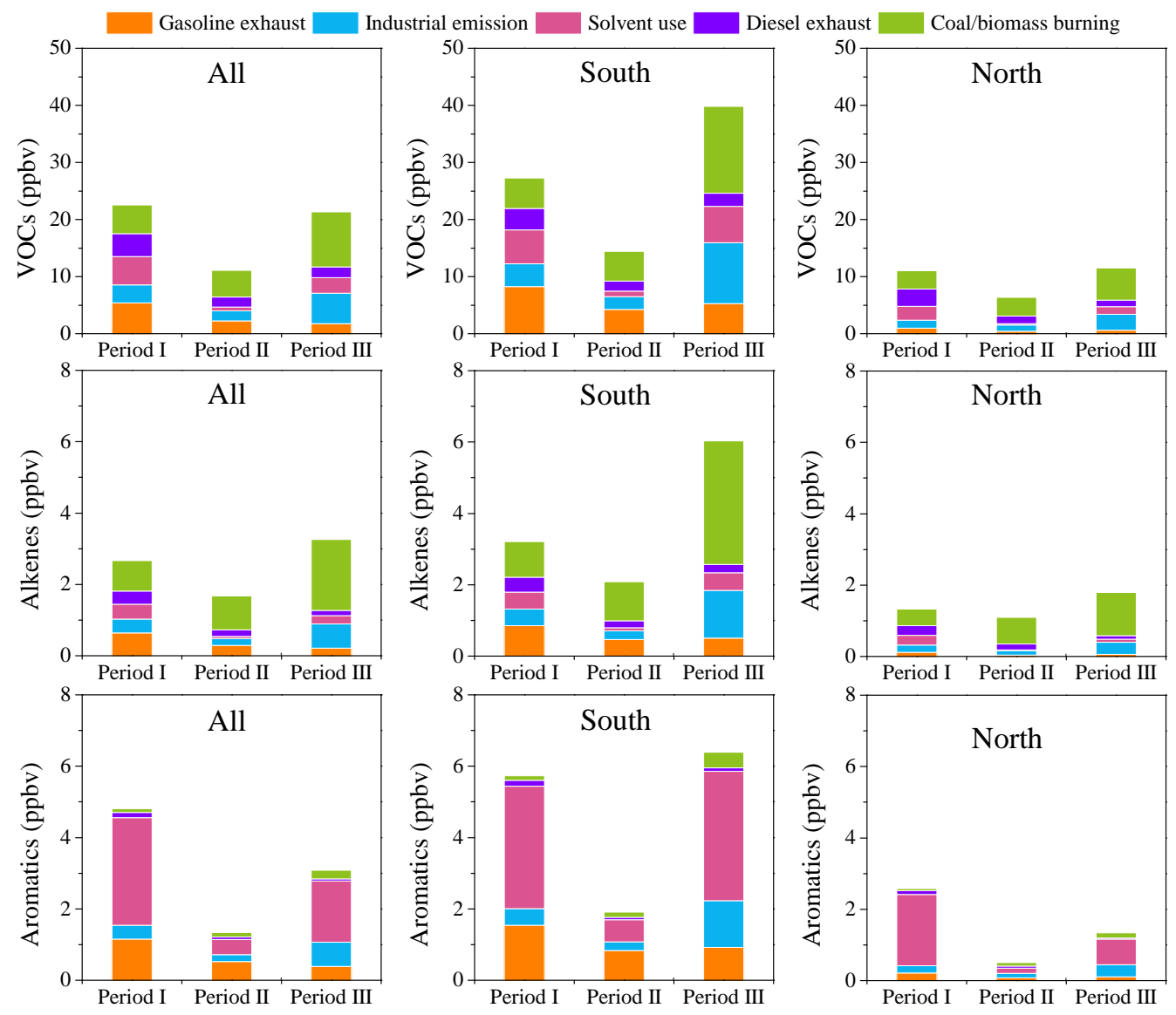

Figure 9. Source contributions of VOCs and reactive alkenes and aromatics in all samples and in air masses from the southern and northern regions during periods I, II and III.

reductions in solvent use, diesel exhaust and gasoline exhaust during period II relative to period I could explain $46.5 \%$, $35.8 \%$ and $11.9 \%$ of the total reduction in VOCs, respectively. Consequently, control measures related to solvent use and gasoline exhaust were more effective in the southern regions, while the control of solvent use and diesel exhaust emissions was more effective in the northern region.

\subsubsection{Source contributions to the SOAFP}

With the PMF source apportionment results, the contributions of the SOAFP of different sources were further estimated. As shown in Fig. 10, under low- $\mathrm{NO}_{x}$ conditions, the SOAFP of solvent use was much higher than that of other sources, which was $4.88,0.68$ and $2.89 \mu \mathrm{g} \mathrm{m}^{-3}$, accounting for $56.9 \%, 27.2 \%$ and $54.7 \%$ of the total SOAFP during periods I, II and III, respectively. Gasoline exhaust contributed 19.2, 29.5 and $10.9 \%$, and diesel exhaust contributed $16.5 \%, 26.8 \%$ and $11.3 \%$ of the SOAFP during periods I, II and III, respectively. During period II, with temporary intervention measures, the reduction in SOAFP was mainly due to reduced contributions from solvent use, gasoline exhaust and diesel exhaust, which could explain $69.1 \%, 14.9 \%$ and $12.2 \%$ of the reduction in SOAFP, respectively. Under high$\mathrm{NO}_{x}$ conditions, the calculated reduction in SOAFP during period II relative to period I could largely be explained by the reduced contributions from solvent use, diesel exhaust and gasoline exhaust, which accounted for $54.0 \%, 25.8 \%$ and $16.8 \%$ of the reduction in SOAFP, respectively.

It is worth noting that recent chamber studies revealed that aromatic hydrocarbons and traditional VOCs could not fully explain the SOA formed during atmospheric aging of source emissions (Zhao et al., 2014, 2015; T. Liu et al., 2015; Deng et al., 2017; Fang et al., 2017), particularly for emissions from diesel vehicles or biomass burning (Zhao et al., 2015; Deng et al., 2017; Fang et al., 2017). Therefore the discussion on the SOAFP in this study is limited to traditional anthropogenic SOA precursor species (mainly aromatic hydrocarbons), and intermediate-volatility organic compounds (IVOCs), which are important SOA precursors (Zhao et al., 2014), should be further considered in order to fully understand the influence of control measures on ambient SOA. 

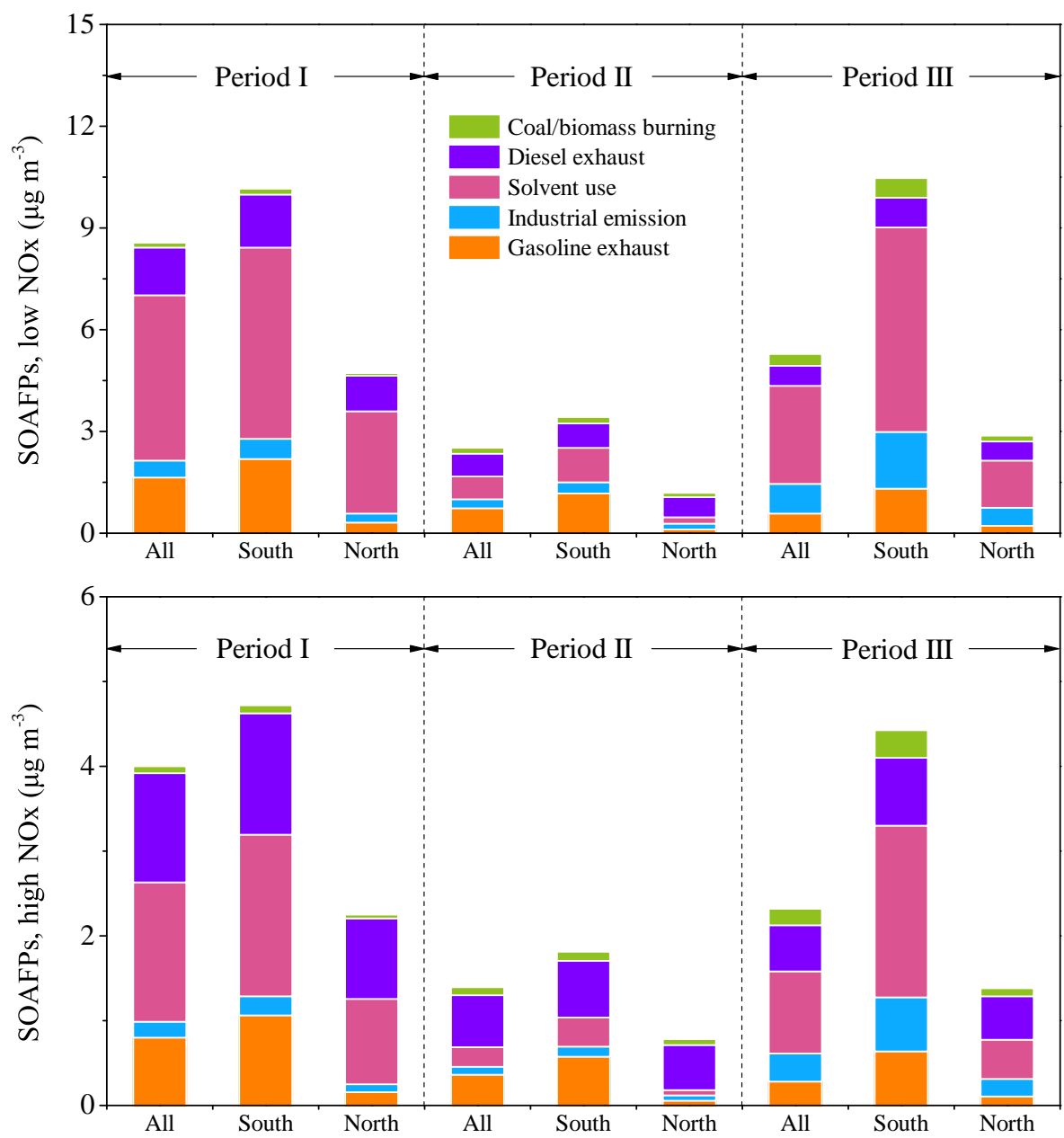

Figure 10. Contributions to SOAFPs from different sources in the air masses from the southern and northern regions during periods I, II and III.

\section{Conclusions}

During severe wintertime haze events in recent years in Beijing, SOA often composed higher fractions of organic aerosols, yet their precursor VOCs in ambient air during winter are not well understood, especially in rural areas. In this study, we collected ambient air samples from 25 October to 31 December in 2014 at a rural site on the campus of UCAS in northern Beijing. The APEC summit was held in Beijing on 5-11 November 2014, temporary control measures were adopted to improve the air quality, and the so-called "APEC Blue" was achieved due to the enhanced emission control. Therefore, we took advantage of this opportunity to see how the control measures influenced the ambient VOCs in rural areas. Conversely, wintertime heating from coal burning has been regarded as a major contributor to wintertime PM pollution and haze events; thus, we also compared the ambient VOC levels and composition before and after the start of central heating on 15 November and investigated the influence of wintertime heating on ambient VOCs based on our observation at a rural site.

We observed that during the enhanced emission control period (period II; 3-12 November), the average mixing ratios of VOCs decreased $\sim 50 \%$ compared to those before or after that period. In addition, the ozone and SOA formation potential accordingly decreased by $\sim 50 \%$ and $\sim 70 \%$, respectively, as a result of the temporary intervention measures implemented during period II. The larger decrease in SOA formation potentials was attributable to more effective control over aromatic hydrocarbons mainly from solvent use. Based on PMF source apportionment, the control of trafficrelated emissions (gasoline and diesel exhaust) and solvent use could explain $47.9 \%$ and $37.6 \%$ of the reduction in ambient VOCs. This result thus offered an observation-based evaluation of the temporary emission control measures.

Through back trajectory analysis, we could compare ambient VOCs with the change in wind direction and thus further investigate the source emission strengths in different regions. 
The total mixing ratios of VOCs in southerly air masses were 2.3, 2.3 and 2.9 times those in northerly air masses before, during and after the period with temporary emission control for the APEC summit. VOC episodes during the campaign all occurred under southerly winds. This confirms that emission control in the southern urbanized regions is crucial for reducing the ambient VOCs.

As residential coal/biomass burning was not controlled during the APEC summit, its contribution to the ambient mixing ratios of VOCs was similar between period I and period II, although the contribution percentages of coal/biomass burning became the largest on average due to decreases in the percentages of other sources. During period III, with emissions from burning solid fuels for household heating, coal/biomass burning became the largest source, accounting for $45.1 \%$ of the VOCs. Specifically, during period III, coal/biomass combustion contributed $38.2 \%$ of the VOCs in southerly air masses (or in the southern regions), and $48.8 \%$ of the VOCs in northerly air masses (or in the northern regions).

The findings of this study will provide useful information for the emission control strategy of VOCs. A comparison of VOCs between period I (without intervention measures) and period II (with intervention measures) revealed that the temporary intervention measures mostly targeted at controls in the traffic and industry (industrial processes and solvent use) sectors are very effective at reducing reactive alkenes and aromatics and thereby reducing the OFPs and SOAFPs of VOCs in ambient air. Therefore, enhancing emission control for solvent use (especially solvents with aromatic hydrocarbons) and vehicle exhaust would benefit reducing the VOCrelated air pollution. However, as observed in this study, even in megacities like Beijing, burning raw coal or biomass for household heating in winter could contribute nearly half of VOCs in ambient air. If the emission control over residential burning of solid fuels is underappreciated, the intervention measures targeted at traffic and industry sectors would not be so effective in the wintertime heating period as in non-heating periods due either to lower $\mathrm{PM}_{2.5}$ as indicated by Liu et al. (2016) or to lower VOCs in ambient air as indicted by this study. In fact, a study by Yu et al. (2018) during the same field campaign of this study demonstrated that, without emission control over residential burning of solid fuels, ambient $\mathrm{PM}_{2.5}$-bound toxic polycyclic aromatic hydrocarbons in rural Beijing during the 2014 APEC summit remained unchanged despite the temporary intervention control measures, and they were largely aggravated after the start of wintertime heating. Therefore, cleaner energy use instead of poor-technology burning of solid fuels for household heating would have tremendous health benefits in lowering both indoor and outdoor air pollution, particularly in heavily polluted winter. It is worth noting that this study was conducted in a rural area of the megacity Beijing. Emissions from residential burning of solid fuels would be a source of greater importance and thus deserve more concern in less developed regions.

Data availability. The data used in this publication are available to the community and can be accessed by request to the corresponding author.

Supplement. The supplement related to this article is available online at: https://doi.org/10.5194/acp-18-12663-2018-supplement.

Author contributions. WQY performed data analysis with contributions from YLZ and XMW. SL, MZ and G-HL helped sampling. ZHH, HNZ and ZFW helped sample analysis. QQY helped with PMF model running. JHT provided trace gas data. WS and MS contributed to paper preparation.

Competing interests. The authors declare that they have no conflict of interest.

Acknowledgements. This study was supported by the National Key Research and Development Program (2016YFC0202204/2017YFC0212802), the Chinese Academy of Sciences (grant no. QYZDJ-SSW-DQC032), the National Natural Science Foundation of China (grant nos. 41673116, 41530641 and 41571130031), and the Guangzhou Science Technology and Innovation Commission (201607020002/201704020135).

Edited by: Thomas Karl

Reviewed by: three anonymous referees

\section{References}

An, J. L., Wang, Y. S., Wu, F. K., and Zhu, B.: Characterizations of volatile organic compounds during high ozone episodes in Beijing, China, Environ. Monit. Assess., 184, 1879-1889, https://doi.org/10.1007/s10661-011-2086-7, 2012.

Atkinson, R.: Atmospheric chemistry of VOCs and $\mathrm{NO}_{x}$, Atmos. Environ., 34, 2063-2101, https://doi.org/10.1016/S13522310(99)00460-4, 2000.

Beijing Municipal Bureau of Statistics (BMBS): Bejing Statistical Yearbook 2016, China Statistics Press, Beijing, 2016.

Blake, D. R. and Rowland, F. S.: Urban leakage of liquefied petroleum gas and its impact on Mexico-city air-quality, Science, 269, 953-956, https://doi.org/10.1126/science.269.5226.953, 1995.

Borbon, A., Locoge, N., Veillerot, M., Galloo, J. C., and Guillermo, R.: Characterisation of NMHCs in a French urban atmosphere: overview of the main sources, Sci. Total Environ., 292, 177-191, https://doi.org/10.1016/S0048-9697(01)01106-8, 2002.

Cabada, J. C., Pandis, S. N., Subramanian, R., Robinson, A. L., Polidori, A., and Turpin, B.: Estimating the secondary organic aerosol contribution to $\mathrm{PM}_{2.5}$ using the 
EC tracer method, Aerosol Sci. Tech., 38, 140-155, https://doi.org/10.1080/02786820390229084, 2004.

Cai, C. J., Geng, F. H., Tie, X. X., Yu, Q., and An, J. L.: Characteristics and source apportionment of VOCs measured in Shanghai, China, Atmos. Environ., 44, 5005-5014, https://doi.org/10.1016/j.atmosenv.2010.07.059, 2010.

Carter, W. P. L.: Update maximum incremental reactivity scale and hydrocarbon bin reactivities for regulatory application, California Air Resources Board Contract 07-339, 2009.

Chang, C. C., Chen, T. Y., Chou, C., and Liu, S. C.: Assessment of traffic contribution to hydrocarbons using 2,2-dimethylbutane as a vehicular indicator, Terr. Atmos. Ocean. Sci., 15, 697-711, https://doi.org/10.3319/TAO.2004.15.4.697(A), 2004.

Cheng, J., Zhang, Y. S., Wang, T., Xu, H., Norris, P., and Pan, W.-P.: Emission of volatile organic compounds (VOCs) during coal combustion at different heating rates, Fuel, 225, 554-562, https://doi.org/10.1016/j.fuel.2018.03.185, 2018.

Deng, W., Hu, Q. H., Liu, T. Y., Wang, X. M., Zhang, Y. L., Song, W., Sun, Y. L., Bi, X. H., Yu, J. Z., Yang, W. Q., Huang, X. Y., Zhang, Z., Huang, Z. H., He, Q. F., Mellouki, A., and George, C.: Primary particulate emissions and secondary organic aerosol (SOA) formation from idling diesel vehicle exhaust in China, Sci. Total Environ., 593-594, 462-469, https://doi.org/10.1016/j.scitotenv.2017.03.088, 2017.

Fang, Z., Deng, W., Zhang, Y., Ding, X., Tang, M., Liu, T., Hu, Q., Zhu, M., Wang, Z., Yang, W., Huang, Z., Song, W., Bi, X., Chen, J., Sun, Y., George, C., and Wang, X.: Open burning of rice, corn and wheat straws: primary emissions, photochemical aging, and secondary organic aerosol formation, Atmos. Chem. Phys., 17, 14821-14839, https://doi.org/10.5194/acp-17-148212017, 2017.

Forstner, H. J. L., Flagan, R. C., and Seinfeld, J. H.: Secondary organic aerosol from the photooxidation of aromatic hydrocarbons: Molecular composition, Environ. Sci. Technol., 31, 1345-1358, https://doi.org/10.1021/es9605376, 1997.

Fu, X. X., Wang, X. M., Hu, Q. H., Li, G. H., Ding, X., Zhang, Y. L., He, Q. F., Liu, T. Y., Zhang, Z., Yu, Q. Q., Shen, R. Q., and Bi, X. H.: Changes in visibility with $\mathrm{PM}_{2.5}$ composition and relative humidity at a background site in the Pearl River Delta region, J. Environ. Sci., 40, 10-19, https://doi.org/10.1016/j.jes.2015.12.001, 2016.

Gentner, D. R., Jathar, S. H., Gordon, T. D., Bahreini, R., Day, D. A., El Haddad, I., Hayes, P. L., Pieber, S. M., Platt, S. M., de Gouw, J., Goldstein, A. H., Harley, R. A., Jimenez, J. L., Prevot, A. S. H., and Robinson, A. L.: Review of urban secondary organic aerosol formation from gasoline and diesel motor vehicle emissions, Environ. Sci. Technol., 51, 1074-1093, https://doi.org/10.1021/acs.est.6b04509, 2017.

Guo, H., Wang, T., and Louie, P. K. K.: Source apportionment of ambient non-methane hydrocarbons in Hong Kong: Application of a principal component analysis/absolute principal component scores (PCA/APCS) receptor model, Environ. Pollut., 129, 489498, https://doi.org/10.1016/j.envpol.2003.11.006, 2004.

Guo, H., So, K. L., Simpson, I. J., Barletta, B., Meinardi, S., and Blake, D. R.: C1-C8 volatile organic compounds in the atmosphere of Hong Kong: Overview of atmospheric processing and source apportionment, Atmos. Environ., 41, 1456-1472, https://doi.org/10.1016/j.atmosenv.2006.10.011, 2007.
Guo, S., Hu, M., Zamora, M. L., Peng, J. F., Shang, D. J., Zheng, J., Du, Z. F., Wu, Z. J., Shao, M., Zeng, L. M., Molina, M. J., and Zhang, R. Y.: Elucidating severe urban haze formation in China, P. Natl. Acad. Sci. USA, 111, 17373-17378, https://doi.org/10.1073/pnas.1419604111, 2014.

Hao, J. M. and Wang, L. T.: Improving urban air quality in China: Beijing case study, Japca J. Air Waste Ma., 55, 1298-1305, https://doi.org/10.1080/10473289.2005.10464726, 2005.

Huang, K., Zhang, X. Y., and Lin, Y. F.: The "APEC Blue" phenomenon: Regional emission control effects observed from space, Atmos. Res., 164-165, 65-75, https://doi.org/10.1016/j.atmosres.2015.04.018, 2015.

Huang, R. J., Zhang, Y. L., Bozzetti, C., Ho, K. F., Cao, J. J., Han, Y. M., Daellenbach, K. R., Slowik, J. G., Platt, S. M., Canonaco, F., Zotter, P., Wolf, R., Pieber, S. M., Bruns, E. A., Crippa, M., Ciarelli, G., Piazzalunga, A., Schwikowski, M., Abbaszade, G., Schnelle-Kreis, J., Zimmermann, R., An, Z. S., Szidat, S., Baltensperger, U., El Haddad, I., and Prevot, A. S. H.: High secondary aerosol contribution to particulate pollution during haze events in China, Nature, 514, 218-222, https://doi.org/10.1038/nature13774, 2014.

Huang, X.-F., He, L.-Y., Hu, M., Canagaratna, M. R., Sun, Y., Zhang, Q., Zhu, T., Xue, L., Zeng, L.-W., Liu, X.-G., Zhang, Y.-H., Jayne, J. T., Ng, N. L., and Worsnop, D. R.: Highly time-resolved chemical characterization of atmospheric submicron particles during 2008 Beijing Olympic Games using an Aerodyne High-Resolution Aerosol Mass Spectrometer, Atmos. Chem. Phys., 10, 8933-8945, https://doi.org/10.5194/acp-108933-2010, 2010.

Huang, X. Y., Zhang, Y. L., Yang, W. Q., Huang, Z. Z., Wang, Y. J., Zhang, Z., He, Q. F., Lü, S. J., Huang, Z. H., Bi, X. H., and Wang, X. M.: Effect of traffic restriction on reducing ambient volatile organic compounds (VOCs): observation-based evaluation during a traffic restriction drill in Guangzhou, China, Atmos. Environ., 161, 61-70, https://doi.org/10.1016/j.atmosenv.2017.04.035, 2017.

Ji, D. S., Wang, Y. S., Wang, L. L., Chen, L. F., Hu, B., Tang, G. Q., Xin, J. Y., Song, T., Wen, T. X., Sun, Y., Pan, Y. P., and Liu, Z. R.: Analysis of heavy pollution episodes in selected cities of northern China, Atmos. Environ., 50, 338-348, https://doi.org/10.1016/j.atmosenv.2011.11.053, 2012.

Juda-Rezler, K., Reizer, M., and Oudinet, J. P.: Determination and analysis of $\mathrm{PM}_{10}$ source apportionment during episodes of air pollution in Central Eastern European urban areas: The case of wintertime 2006, Atmos. Environ., 45, 6557-6566, https://doi.org/10.1016/j.atmosenv.2011.08.020, 2011.

Kelly, F. J. and Zhu, T.: Transport solutions for cleaner air, Science, 352, 934-936, https://doi.org/10.1126/science.aaf3420, 2016.

Lau, A. K. H., Yuan, Z. B., Yu, J. Z., and Louie, P. K. K.: Source apportionment of ambient volatile organic compounds in Hong Kong, Sci. Total Environ., 408, 4138-4149, https://doi.org/10.1016/j.scitotenv.2010.05.025, 2010.

Lelieveld, J., Evans, J. S., Fnais, M., Giannadaki, D., and Pozzer, A.: The contribution of outdoor air pollution sources to premature mortality on a global scale, Nature, 525, 367-371, https://doi.org/10.1038/nature15371, 2015.

Leuchner, M. and Rappenglück, B.: VOC source-receptor relationships in Houston during TexAQS-II, Atmos. Environ., 44, 40564067, https://doi.org/10.1016/j.atmosenv.2009.02.029, 2010. 
Li, H., Zhang, Q., Zhang, Q., Chen, C., Wang, L., Wei, Z., Zhou, S., Parworth, C., Zheng, B., Canonaco, F., Prévôt, A. S. H., Chen, P., Zhang, H., Wallington, T. J., and He, K.: Wintertime aerosol chemistry and haze evolution in an extremely polluted city of the North China Plain: significant contribution from coal and biomass combustion, Atmos. Chem. Phys., 17, 4751-4768, https://doi.org/10.5194/acp-17-4751-2017, 2017.

Li, J., Xie, S. D., Zeng, L. M., Li, L. Y., Li, Y. Q., and Wu, R. R.: Characterization of ambient volatile organic compounds and their sources in Beijing, before, during, and after Asia-Pacific Economic Cooperation China 2014, Atmos. Chem. Phys., 15, 7945-7959, https://doi.org/10.5194/acp-15-7945-2015, 2015.

Lim, S., Vos, T., Flaxman, A. D., et al.: A comparative risk assessment of burden of disease and injury attributable to 67 risk factors and risk factor clusters in 21 regions, 1990-2010: a systematic analysis for the Global Burden of Disease Study 2010, Lancet, 380, 2224-2260, https://doi.org/10.1016/s0140-6736(12)617668, 2012.

Lim, Y. B. and Ziemann, P. J.: Effects of molecular structure on aerosol yields from $\mathrm{OH}$ radical-initiated reactions of linear, branched, and cyclic alkanes in the presence of $\mathrm{NO}_{x}$, Environ. Sci. Technol., 43, 2328-2334, https://doi.org/10.1021/es803389s, 2009.

Liu, C. T., Zhang, C. L., Mu, Y. J., Liu, J. F., and Zhang, Y. Y.: Emission of volatile organic compounds from domestic coal stove with the actual alternation of flaming and smoldering combustion processes, Environ. Pollut., 221, 385-391, https://doi.org/10.1016/j.envpol.2016.11.089, 2017.

Liu, J., Mauzerall, D. L., Chen, Q., Zhang, Q., Song, Y., Peng, W., Klimont, Z., Qiu, X. H., Zhang, S. Q., Hu, M., Lin, W. L., Smith, K. R., and Zhu, T.: Air pollutant emissions from Chinese households: A major and underappreciated ambient pollution source, P. Natl. Acad. Sci. USA, 113, 7756-7761, https://doi.org/10.1073/pnas.1604537113, 2016.

Liu, J. F., Mu, Y. J., Zhang, Y. J., Zhang, Z. M., Wang, X. K., Liu, Y. J., and Sun, Z. Q.: Atmospheric levels of BTEX compounds during the 2008 Olympic Games in the urban area of Beijing, Sci. Total Environ., 408, 109-116, https://doi.org/10.1016/j.scitotenv.2009.09.026, 2009.

Liu, J. G., Xie, P. H., Wang, Y. S., Wang, Z. F., He, H., and Liu, W. Q.: Haze observation and control measure evaluation in Jing-Jin-Ji (Beijing, Tianjin, Hebei) area during the period of the Asia-Pacific Economic Cooperation (APEC) Meeting, Bulletin of Chinese Academy of Sciences, 30, 368-377, https://doi.org/10.16418/j.issn.1000-3045.2015.03.011, 2015 (in Chinese).

Liu, K. K., Quan, J. N., Mu, Y. J., Zhang, Q., Liu, J. F., Gao, Y., Chen, P. F., Zhao, D. L., and Tian, H. J.: Aircraft measurements of BTEX compounds around Beijing city, Atmos. Environ., 73, 11-15, https://doi.org/10.1016/j.atmosenv.2013.02.050, 2013.

Liu, K. K., Zhang, C. L., Cheng, Y., Liu, C. T., Zhang, H. X., Zhang, G., Sun, X., and Mu, Y. J.: Serious BTEX pollution in rural area of the North China Plain during winter season, J. Environ. Sci., 30, 186-190, https://doi.org/10.1016/j.jes.2014.05.056, 2015.

Liu, T., Wang, X., Deng, W., Hu, Q., Ding, X., Zhang, Y., He, Q., Zhang, Z., Lü, S., Bi, X., Chen, J., and Yu, J.: Secondary organic aerosol formation from photochemical aging of lightduty gasoline vehicle exhausts in a smog chamber, Atmos.
Chem. Phys., 15, 9049-9062, https://doi.org/10.5194/acp-159049-2015, 2015.

Liu, Y., Shao, M., Fu, L. L., Lu, S. H., Zeng, L. M., and Tang, D. G.: Source profiles of volatile organic compounds (VOCs) measured in China: Part I, Atmos. Environ., 42, 6247-6260, https://doi.org/10.1016/j.atmosenv.2008.01.070, 2008.

Liu, Z. R., Hu, B., Wang, L. L., Wu, F. K., Gao, W. K., and Wang, Y. S.: Seasonal and diurnal variation in particulate matter $\left(\mathrm{PM}_{10}\right.$ and $\left.\mathrm{PM}_{2.5}\right)$ at an urban site of Beijing: Analyses from a 9-year study, Environ. Sci. Pollut. R., 22, 627-642, https://doi.org/10.1007/s11356-014-3347-0, 2015.

Lonati, G., Giugliano, M., Butelli, P., Romele, L., and Tardivo, R.: Major chemical components of $\mathrm{PM}_{2.5}$ in Milan (Italy), Atmos. Environ., 39, 1925-1934, https://doi.org/10.1016/j.atmosenv.2004.12.012, 2005.

Lu, S. H., Liu, Y., Shao, M., and Huang, S.: Chemical speciation and anthropogenic sources of ambient volatile organic compounds (VOCs) during summer in Beijing, 2004, Front. Environ. Sci. Engin. China., 1, 147-152, https://doi.org/10.1007/s11783-0070026-0, 2007.

Martin, W. J., Glass, R. I., Balbus, J. M., and Collins, F. S.: A major environmental cause of death, Science, 334, 180-181, https://doi.org/10.1126/science.1213088, 2011.

McDonald, B. C., Goldstein, A. H., and Harley, R. A.: Long-term trends in California mobile source emissions and ambient concentrations of black carbon and organic aerosol, Environ. Sci Technol., 49, 5178-5188, https://doi.org/10.1021/es505912b, 2015.

Ng, N. L., Kroll, J. H., Chan, A. W. H., Chhabra, P. S., Flagan, R. C., and Seinfeld, J. H.: Secondary organic aerosol formation from $m$-xylene, toluene, and benzene, Atmos. Chem. Phys., 7, 3909-3922, https://doi.org/10.5194/acp-7-3909-2007, 2007.

O’Dowd, C. D., Aalto, P., Hameri, K., Kulmala, M., and Hoffmann, T.: Aerosol formation - Atmospheric particles from organic vapours, Nature, 416, 497-498, https://doi.org/10.1038/416497a, 2002.

Odum, J. R., Jungkamp, T. P. W., Griffin, R. J., Flagan, R. C., and Seinfeld, J. H.: The atmospheric aerosol-forming potential of whole gasoline vapor, Science, 276, 96-99, https://doi.org/10.1126/science.276.5309.96, 1997.

Ortega, A. M., Hayes, P. L., Peng, Z., Palm, B. B., Hu, W., Day, D. A., Li, R., Cubison, M. J., Brune, W. H., Graus, M., Warneke, C., Gilman, J. B., Kuster, W. C., de Gouw, J., GutiérrezMontes, C., and Jimenez, J. L.: Real-time measurements of secondary organic aerosol formation and aging from ambient air in an oxidation flow reactor in the Los Angeles area, Atmos. Chem. Phys., 16, 7411-7433, https://doi.org/10.5194/acp16-7411-2016, 2016.

Ou, J. M., Guo, H., Zheng, J. Y., Cheung, K., Louie, P. K. K., Ling, Z. H., and Wang, D. W.: Concentrations and sources of nonmethane hydrocarbons (NMHCs) from 2005 to 2013 in Hong Kong: A multi-year real-time data analysis, Atmos. Environ., 103, 196-206, https://doi.org/10.1016/j.atmosenv.2014.12.048, 2015.

Paatero, P.: Least squares formulation of robust non-negative factor analysis, Chemometr. Intell. Lab., 37, 23-35, https://doi.org/10.1016/S0169-7439(96)00044-5, 1997.

Paatero, P. and Tapper, U.: Positive matrix factorization: A non-negative factor model with optimal utilization of er- 
ror estimates of data values, Environmetrics, 5, 111-126, https://doi.org/10.1002/env.3170050203, 1994.

Parrish, D. D., Kuster, W. C., Shao, M., Yokouchi, Y., Kondo, Y., Goldan, P. D., de Gouw, J. A., Koike, M., and Shirai, T.: Comparison of air pollutant emissions among mega-cities, Atmos. Environ., 43, 6435-6441, https://doi.org/10.1016/j.atmosenv.2009.06.024, 2009.

Sari, D. and Bayram, A.: Quantification of emissions from domestic heating in residential areas of İzmir, Turkey and assessment of the impact on local/regional air-quality, Sci. Total Environ., 488489, 429-436, https://doi.org/10.1016/j.scitotenv.2013.11.033, 2014.

Sato, K., Takami, A., Isozaki, T., Hikida, T., Shimono, A., and Imamura, T.: Mass spectrometric study of secondary organic aerosol formed from the photo-oxidation of aromatic hydrocarbons, Atmos. Environ., 44, 1080-1087, https://doi.org/10.1016/j.atmosenv.2009.12.013, 2010.

Shao, M., Lu, S. H., Liu, Y., Xie, X., Chang, C. C., Huang, S., and Chen, Z. M.: Volatile organic compounds measured in summer in Beijing and their role in ground-level ozone formation, J. Geophys. Res.-Atmos., 114, D00G06, https://doi.org/10.1029/2008jd010863, 2009.

Shrivastava, M., Easter, R. C., Liu, X. H., Zelenyuk, A., Singh, B., Zhang, K., Ma, P.-L., Chand, D., Ghan, S., Jimenez, J. L., Zhang, Q., Fast, J., Rasch, P. J., and Tiitta, P.: Global transformation and fate of SOA: Implications of low-volatility SOA and gas-phase fragmentation reactions, J. Geophys. Res.-Atmos., 120, 41694195, https://doi.org/10.1002/2014jd022563, 2015.

Song, Y., Shao, M., Liu, Y., Lu, S. H., Kuster, W., Goldan, P., and Xie, S. D.: Source apportionment of ambient volatile organic compounds in Beijing, Environ. Sci. Technol., 41, 4348-4353, https://doi.org/10.1021/es0625982, 2007.

Streets, D. G., Fu, J. S., Jang, C. J., Hao, J. M., He, K. B., Tang, X. Y., Zhang, Y. H., Wang, Z. F., Li, Z. P., Zhang, Q., Wang, L. T., Wang, B. Y., and Yu, C.: Air quality during the 2008 Beijing Olympic Games, Atmos. Environ., 41, 480-492, https://doi.org/10.1016/j.atmosenv.2006.08.046, 2007.

Subramanian, M.: Deadly dinners, Nature, 509, 548-551, https://doi.org/10.1038/509548a, 2014.

Suthawaree, J., Kato, S., Okuzawa, K., Kanaya, Y., Pochanart, P., Akimoto, H., Wang, Z., and Kajii, Y.: Measurements of volatile organic compounds in the middle of Central East China during Mount Tai Experiment 2006 (MTX2006): observation of regional background and impact of biomass burning, Atmos. Chem. Phys., 10, 1269-1285, https://doi.org/10.5194/acp10-1269-2010, 2010.

Tang, X., Wang, Z. F., Zhu, J., Gbaguidi, A. E., Wu, Q. Z, Li, J., and Zhu, T.: Sensitivity of ozone to precursor emissions in urban Beijing with a Monte Carlo scheme, Atmos. Environ., 44, 38333842, https://doi.org/10.1016/j.atmosenv.2010.06.026, 2010.

Wang, B., Shao, M., Lu, S. H., Yuan, B., Zhao, Y., Wang, M., Zhang, S. Q., and Wu, D.: Variation of ambient non-methane hydrocarbons in Beijing city in summer 2008, Atmos. Chem. Phys., 10, 5911-5923, https://doi.org/10.5194/acp-10-5911-2010, 2010.

Wang, M., Zhu, T., Zheng, J., Zhang, R. Y., Zhang, S. Q., Xie, X. X., Han, Y. Q., and Li, Y.: Use of a mobile laboratory to evaluate changes in on-road air pollutants during the Beijing 2008 Summer Olympics, Atmos. Chem. Phys., 9, 8247-8263, https://doi.org/10.5194/acp-9-8247-2009, 2009.
Wang, M., Shao, M., Lu, S. H., Yang, Y. D., and Chen, W. T.: Evidence of coal combustion contribution to ambient VOCs during winter in Beijing, Chin. Chem. Lett., 24, 829-832, https://doi.org/10.1016/j.cclet.2013.05.029, 2013.

Wang, S. W., Zhao, M., Xing, J., Wu, Y., Zhou, Y., Lei, Y., He, K. B., Fu, L. X., and Hao, J. M.: Quantifying the Air Pollution Emission Reduction during the 2008 Olymic Games in Beijing, Environ. Sci. Technol., 44, 2490-2496, https://doi.org/10.1021/es9028167, 2010.

Wang, X. M., Sheng, G. Y., Fu, J. M., Chan, C. Y., Lee, S. G., Chan, L. Y., and Wang, Z. S.: Urban roadside aromatic hydrocarbons in three cities of the Pearl River Delta, People's Republic of China, Atmos. Environ., 36, 5141-5148, https://doi.org/10.1016/s13522310(02)00640-4, 2002.

Wang, Y. S., Yao, L., Wang, L. L., Liu, Z. R., Ji, D. S., Tang, G. Q., Zhang, J. K., Sun, Y., Hu, B., and Xin, J. Y.: Mechanism for the formation of the January 2013 heavy haze pollution episode over central and eastern China, Sci. China Earth Sci., 57, 14-25, https://doi.org/10.1007/s11430-013-4773-4, 2014.

Wang, Z. S., Li, Y. T., Chen, T., Li, L. J., Liu, B. X., Zhang, D. W., Sun, F., Wei, Q., Jiang, L., and Pan, L. B.: Changes in atmospheric composition during the 2014 APEC conference in Beijing, J. Geophys. Res.-Atmos., 120, 12695-12707, https://doi.org/10.1002/2015jd023652, 2015.

Xu, J. Y., Zhuo, J. K., Zhu, Y. N., Pan, Y., and Yao, Q.: Analysis of volatile organic pyrolysis products of bituminous and anthracite coals with single-photon ionization time-of-flight mass spectrometry and gas chromatography/mass spectrometry, Energ. Fuel, 31, 730-737, https://doi.org/10.1021/acs.energyfuels.6b02335, 2017.

Xu, W. Q., Sun, Y. L., Chen, C., Du, W., Han, T. T., Wang, Q. Q., Fu, P. Q., Wang, Z. F., Zhao, X. J., Zhou, L. B., Ji, D. S., Wang, P. C., and Worsnop, D. R.: Aerosol composition, oxidation properties, and sources in Beijing: results from the 2014 Asia-Pacific Economic Cooperation summit study, Atmos. Chem. Phys., 15, 13681-13698, https://doi.org/10.5194/acp-1513681-2015, 2015.

Xue, Y. F., Zhou, Z., Nie, T., Wang, K., Nie, L., Pan, T., Wu, X. Q., Tian, H. Z., Zhong, L. H., Li, J., Liu, H. J., Liu, S. H., and Shao, P. Y.: Trends of multiple air pollutants emissions from residential coal combustion in Beijing and its implication on improving air quality for control measures, Atmos. Environ., 142, 303-312, https://doi.org/10.1016/j.atmosenv.2016.08.004, 2016.

Yao, Z. L., Zhang, Y. Z., Shen, X. B., Wang, X. T., Wu, Y., He, K. B.: Impacts of temporary traffic control measures on vehicular emissions during the Asian Games in Guangzhou, China, Japca J. Air Waste Ma., 63, 11-19, https://doi.org/10.1080/10962247.2012.724041, 2013.

Yokelson, R. J., Christian, T. J., Karl, T. G., and Guenther, A.: The tropical forest and fire emissions experiment: laboratory fire measurements and synthesis of campaign data, Atmos. Chem. Phys., 8, 3509-3527, https://doi.org/10.5194/acp-8-3509-2008, 2008.

Yu, Q. Q., Yang, W. Q., Zhu, M., Gao, B., Li, S., Li, G. H., Fang, H., Zhou, H. S., Zhang, H. N., Wu, Z. F., Song, W., Tan, J. H., Zhang, Y. L., Bi, X. H., Chen, L. G., and Wang, X. M.: Ambient $\mathrm{PM}_{2.5}$-bound polycyclic aromatic hydrocarbons (PAHs) in rural Beijing: Unabated with enhanced temporary emission control during the 2014 APEC summit and largely aggravated after 
the start of wintertime heating, Environ. Pollut., 238, 532-542, https://doi.org/10.1016/j.envpol.2018.03.079, 2018.

Yuan, B., Shao, M., Lu, S. H., and Wang, B.: Source profiles of volatile organic compounds associated with solvent use in Beijing, China, Atmos. Environ., 44, 1919-1926, https://doi.org/10.1016/j.atmosenv.2010.02.014, 2010.

Yuan, Z. B., Lau, A. K. H., Shao, M., Louie, P. K. K., Liu, S. C., and Zhu, T.: Source analysis of volatile organic compounds by positive matrix factorization in urban and rural environments in Beijing, J. Geophys. Res., 114, D00G15, https://doi.org/10.1029/2008jd011190, 2009.

Yuan, Z. B., Zhong, L. J., Lau, A. K. H., Yu, J. Z., and Louie, P. K. K.: Volatile organic compounds in the Pearl River Delta: Identification of source regions and recommendations for emissionoriented monitoring strategies, Atmos. Environ., 76, 162-172, https://doi.org/10.1016/j.atmosenv.2012.11.034, 2013.

Zhang, J. K., Sun, Y., Wu, F. K., Sun, J., and Wang, Y. S.: The characteristics, seasonal variation and source apportionment of VOCs at Gongga Mountain, China, Atmos. Environ., 88, 297305, https://doi.org/10.1016/j.atmosenv.2013.03.036, 2014a.

Zhang, J. K., Sun, Y., Liu, Z. R., Ji, D. S., Hu, B., Liu, Q., and Wang, Y. S.: Characterization of submicron aerosols during a month of serious pollution in Beijing, 2013, Atmos. Chem. Phys., 14, 2887-2903, https://doi.org/10.5194/acp-14-2887-2014, 2014 b.

Zhang, J. K., Wang, L. L., Wang, Y. H., and Wang, Y. S.: Submicron aerosols during the Beijing Asia-Pacific Economic Cooperation conference in 2014, Atmos. Environ., 124, 224-231, https://doi.org/10.1016/j.atmosenv.2015.06.049, 2016.

Zhang, Q., He, K. B., and Huo, H.: Policy: Cleaning China's air, Nature, 484, 161-162, https://doi.org/10.1038/484161a, 2012.

Zhang, Y. J., Mu, Y. J., Liu, J. F., and Mellouki, A.: Levels, sources and health risks of carbonyls and BTEX in the ambient air of Beijing, China, J. Environ. Sci., 24, 124-130, https://doi.org/10.1016/S1001-0742(11)60735-3, 2012.

Zhang, Y. J., Mu, Y. J., Meng, F., Li, H., Wang, X. Z., Zhang, W. Q., Mellouki, A., Gao, J., Zhang, X. M., Wang, S. L., and Chai, F. H.: The pollution levels of BTEX and carbonyls under haze and non-haze days in Beijing, China, Sci. Total Environ., 490, 391-396, https://doi.org/10.1016/j.scitotenv.2014.05.025, 2014.

Zhang, Y. S., Shao, M., Lin, Y., Luan, S. J., Mao, N., Chen, W. T., and Wang, M.: Emission inventory of carbonaceous pollutants from biomass burning in the Pearl River Delta Region, China, Atmos. Environ., 76, 189-199, https://doi.org/10.1016/j.atmosenv.2012.05.055, 2013.

Zhang, Y. L., Wang, X. M., Blake, D. R., Li, L. F., Zhang, Z., Wang, S. Y., Guo, H., Lee, F. S. C., Gao, B., Chan, L. Y., Wu, D., and Rowland, F. S.: Aromatic hydrocarbons as ozone precursors before and after outbreak of the 2008 financial crisis in the Pearl River Delta region, south China, J. Geophys. Res.-Atmos., 117, D15306, https://doi.org/10.1029/2011jd017356, 2012.
Zhang, Y. L., Wang, X. M., Barletta, B., Simpson, I. J., Blake, D. R., Fu, X. X., Zhang, Z., He, Q. F., Liu, T. Y., Zhao, X. Y., and Ding, X.: Source attributions of hazardous aromatic hydrocarbons in urban, suburban and rural areas in the Pearl River Delta (PRD) region, J. Hazard. Mater., 250-251, 403-411, https://doi.org/10.1016/j.jhazmat.2013.02.023, 2013a.

Zhang, Y. L., Wang, X. M., Zhang, Z., Lü, S. J., Shao, M., Lee, F. S. C., and Yu, J. Z.: Species profiles and normalized reactivity of volatile organic compounds from gasoline evaporation in China, Atmos. Environ., 79, 110-118, https://doi.org/10.1016/j.atmosenv.2013.06.029, 2013 b.

Zhang, Y. L., Wang, X. M., Zhang, Z., Lü, S. J., Huang, Z. H., and Li, L. F.: Sources of C2-C4 alkenes, the most important ozone nonmethane hydrocarbon precursors in the Pearl River Delta region, Sci. Total Environ., 502, 236-245, https://doi.org/10.1016/j.scitotenv.2014.09.024, 2015.

Zhang, Z., Wang, X. M., Zhang, Y. L., Lü, S. J., Huang, Z. H., Huang, X. Y., and Wang, Y. S.: Ambient air benzene at background sites in China's most developed coastal regions: Exposure levels, source implications and health risks, Sci. Total Environ., 511, 792-800, https://doi.org/10.1016/j.scitotenv.2015.01.003, 2015.

Zhang, Z., Zhang, Y. L., Wang, X. M., Lü, S. J., Huang, Z. H., Huang, X. Y., Yang, W. Q., Wang, Y. S., and Zhang, Q.: Spatiotemporal patterns and source implications of aromatic hydrocarbons at six rural sites across China's developed coastal regions, J. Geophys. Res.-Atmos., 121, 6669-6687, https://doi.org/10.1002/2016jd025115, 2016.

Zhao, Y. L., Hennigan, C. J., May, A. A., Tkacik, D. S., de Gouw, J. A., Gilman, J. B., Kuster, W. C., Borbon, A., and Robinson, A. L.: Intermediate-volatility organic compounds: a large source of secondary organic aerosol, Environ. Sci. Technol., 48, 1374313750, https://doi.org/10.1021/es5035188, 2014.

Zhao, Y. L., Nguyen, N. T., Presto, A. A., Hennigan, C. J., May, A. A., and Robinson, A. L.: Intermediate volatility organic compound emissions from on-road diesel vehicles: Chemical composition, emission factors, and estimated secondary organic aerosol production, Environ. Sci. Technol., 49, 11516-11526, https://doi.org/10.1021/acs.est.5b02841, 2015.

Zheng, J. Y., Yu, Y. F., Mo, Z. W., Zhang, Z., Wang, X. M., Yin, S. S., Peng, K., Yang, Y., Feng, X. Q., and Cai, H. H.: Industrial sector-based volatile organic compound (VOC) source profiles measured in manufacturing facilities in the Pearl River Delta, China, Sci. Total Environ., 456-457, 127-136, https://doi.org/10.1016/j.scitotenv.2013.03.055, 2013.

Zou, Y., Deng, X. J., Zhu, D., Gong, D. C., Wang, H., Li, F., Tan, H. B., Deng, T., Mai, B. R., Liu, X. T., and Wang, B. G.: Characteristics of 1 year of observational data of VOCs, $\mathrm{NO}_{x}$ and $\mathrm{O}_{3}$ at a suburban site in Guangzhou, China, Atmos. Chem. Phys., 15, 6625-6636, https://doi.org/10.5194/acp-15-6625-2015, 2015. 